\title{
A TRANSFORMAÇÃO DA PAISAGEM, DESENHO E FORMA URBANA: O PEU DAS VARGENS E AS QUESTÕES INICIAIS
}

\author{
THE TRANSFORMATION OF LANDSCAPE, DESIGN AND URBAN FORM: \\ THE "PEU VARGENS" AND INITIAL ISSUES
}

Rogerio Goldfeld Cardeman*

\section{RESUMO}

Este artigo tem como objetivo contextualizar, no âmbito da pesquisa de doutorado, o Projeto de Estruturação Urbana (PEU) da região conhecida como Vargens, na zona oeste da cidade do Rio de Janeiro. Através do histórico da região e da análise do Plano Urbanístico Básico de 1977, levantam-se as primeiras questões sobre sua iminente aplicação, a partir de sua promulgação, em 2009, pelos agentes imobiliários atraídos pela proximidade com a área onde será implantada parte dos equipamentos olímpicos para os jogos de 2016. Discute-se também a influência na transformação do espaço urbano e no sistema de espaços livres da região.

Palavras-chave: Espaços livres de edificação. Desenho urbano. Forma urbana. PEU. Rio de Janeiro.

\section{ABSTRACT}

This paper aims to contextualize, as part of my PhD research Project, the Urban Structure Plan (PEU) in the region known as Vargens in the west of the city of Rio de Janeiro. Through historical analysis of the region and of the Urban Basic Plan of 1977, arise the first questions about its application, since its enactment in 2009, by the real estate agents attracted by their proximity to the area where the equipment will be deployed for the Olympic games of 2016. The paper also discusses Peu's influence on the transformation of urban space and of the system of open spaces in the region.

Keywords: Open spaces. Urban design. Urban form. PEU. Rio de Janeiro.

\section{INTRODUÇÃO}

Este primeiro ano da pesquisa de doutorado - através das cadeiras cursadas no Programa de Pós-Graduação em Arquitetura da Faculdade de Arquitetura da Universidade Federal do Rio de Janeiro (PROARQ/FAU-UFRJ), bem como de seminários de pesquisa e participação da pesquisa Sistema de Espaços Livres (SEL-RJ) e Mudanças

Doutorando em Arquitetura pelo Programa de Pós-Graduação em Arquitetura da Faculdade de Arquitetura da Universidade Federal do Rio de Janeiro (PROARQ-FAU-UFRJ). Pesquisador do Grupo SEL-RJ. Avenida Nossa Senhora de Copacabana, 819, sala 906, CEP 22050-002, Rio de Janeiro, RJ, Brasil cardeman@gmail.com 
Climáticas ${ }^{1}$ e as Formas de Ocupação Urbana - trouxe à tona várias questões que farão parte deste estudo. Questões como planejamento urbano, desenho, forma urbana e o sistema de espaços livres foram estudadas e debatidas com colegas e orientadores.

Este artigo faz parte da pesquisa de doutorado desenvolvida no PROARQ/FAU-UFRJ (com término em 2015) - orientada pelos professores Vera Regina Tângari (UFRJ) e Jonathas Magalhães Pereira da Silva (PUC-Campinas) - e tem como objetivo descrever o início da mesma, seu objeto, o Projeto de Estruturação Urbana (PEU) das Vargens, conceituando-o e contextualizando-o. Trarei elementos históricos e legais que culminaram na aprovação, em 2009, da Lei Complementar Municipal n 104, e que alteraram o curso da ocupação urbana desta região.

\section{DOS ENGENHOS BENEDITINOS AO PROJETO DE ESTRUTURAÇÃO URBANA (PEU)}

Para contextualizar o objeto da pesquisa tratarei de descrevê-lo e situá-lo historicamente no processo de desenvolvimento urbano da cidade. A área de abrangência do PEU está localizada na zona oeste da cidade do Rio de Janeiro, mais conhecida como Baixada de Jacarepaguá (figuras 1 e 2) - constituída, atualmente, por diversos bairros. Dentre eles: Anil, Barra da Tijuca, Camorim, Cidade de Deus, Curicica, Freguesia, Gardênia Azul, Grumari, Itanhangá, Joá, Pechincha, Praça Seca, Recreio dos Bandeirantes, Taquara, Tanque, Vargem Grande, Vargem Pequena.

É uma região caracterizada pela diversidade de ecossistemas, compostos por áreas de dunas, restingas, lagoas e brejos, campos abertos e mata úmida, o que garante a vitalidade da grande quantidade de rios existentes e demonstra a condição de fragilidade ambiental verificada. Portanto, torna-se válido, no momento de grande transformação por que passa a região desde 2009, pesquisar e analisar as mudanças no perfil de seu espaço urbano.

Na época colonial, a ocupação da cidade do Rio de Janeiro era de domínio fundiário religioso. As irmandades determinavam a ocupação do solo e controlavam a construção e o uso das edificações em suas terras. Em 1667, os padres beneditinos receberam como doação os Engenhos de Nossa Senhora do Desterro e de Jacarepaguá, que correspondiam às áreas de Camorim, Vargem Grande e Vargem Pequena (FRIDMAN, 1999).

\footnotetext{
Este projeto vincula-se às linhas de pesquisa do PROARQ/FAU-UFRJ, do Departamento de Geografia da PUC-Rio e do mestrado em Urbanismo da PUC-Campinas, através dos grupos de pesquisa SEL-RJ, Núcleo Interdisciplinar de Pesquisas em Paisagens (NIPP/RJ) e Água no Meio Urbano e Eficiência Energética (SP). Busca integrar pesquisas de diferentes áreas do conhecimento, voltadas para espaços urbanos e periurbanos - em suas dimensões socioambientais - relacionados à: localização dos investimentos públicos em habitação e infraestrutura em espaços não edificados; legislação urbanística; avaliação de intervenções em áreas de alta vulnerabilidade; dinâmica das águas urbanas e sua relação com o uso e ocupação do solo; comportamento de variáveis climáticas nos espaços urbanos consolidados; avaliação da qualidade da cobertura vegetal nas florestas contíguas a áreas urbanizadas.
} 


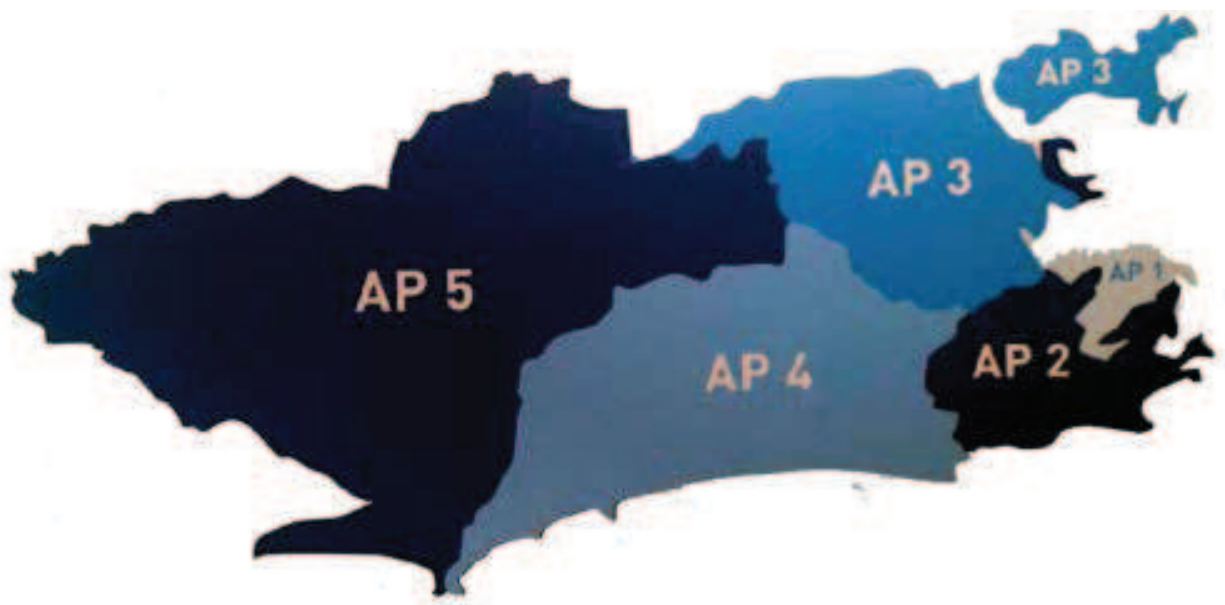

Figura 1 A Área de Planejamento 4 (AP4) corresponde à Baixada de Jacarepaguá. Fonte: Prefeitura da Cidade do Rio de Janeiro - 2012.

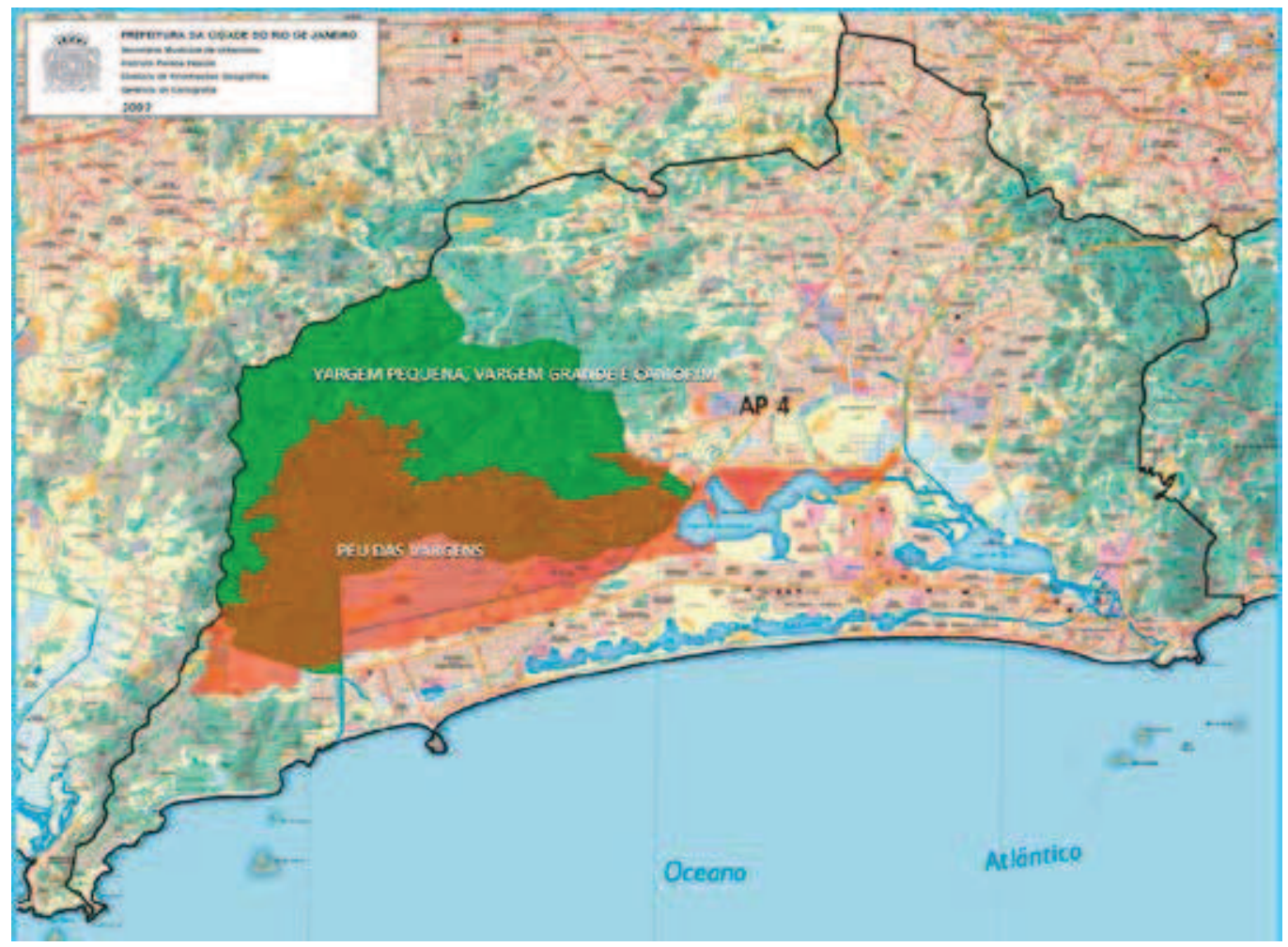

Figura 2 No mapa acima podemos ver a área em verde dos bairros de Vargem Grande e Pequena e Camorim, e a abrangência do PEU das Vargens.

Fonte: Rogerio Goldfeld Cardeman. Sobre mapa da Prefeitura da Cidade do Rio de Janeiro de 2007. 
Nos séculos XVIII e XIX, a atividade agrícola se expandiu devido à incidência de solo fértil e à garantia de irrigação pela presença de diversos rios na região. Com isso, consolidou-se a atividade agrícola dessas terras, que, bem distante do centro administrativo, de acesso difícil, não se prestavam ao assentamento de grandes estratos da população, somente escravos e trabalhadores dos engenhos.

Entre 1857 e 1860, os engenhos movidos a força d'água foram substituídos por modernos engenhos a vapor. $O$ alto custo dessa modernização fez com que os beneditinos, proprietários das terras, ficassem em difícil situação, tendo que tomar grandes empréstimos junto a bancos. Com isso, no final do século XIX - e propiciado pela Lei de Terras de $1850^{2}$-, os padres começaram a dividir seus engenhos e vendê-los à iniciativa privada, a bancos e empresas agrícolas. Em 1930, registrou-se um aquecimento imobiliário com as transações dessas terras, até então pertencentes ao Banco de Crédito Móvel (figura 3).

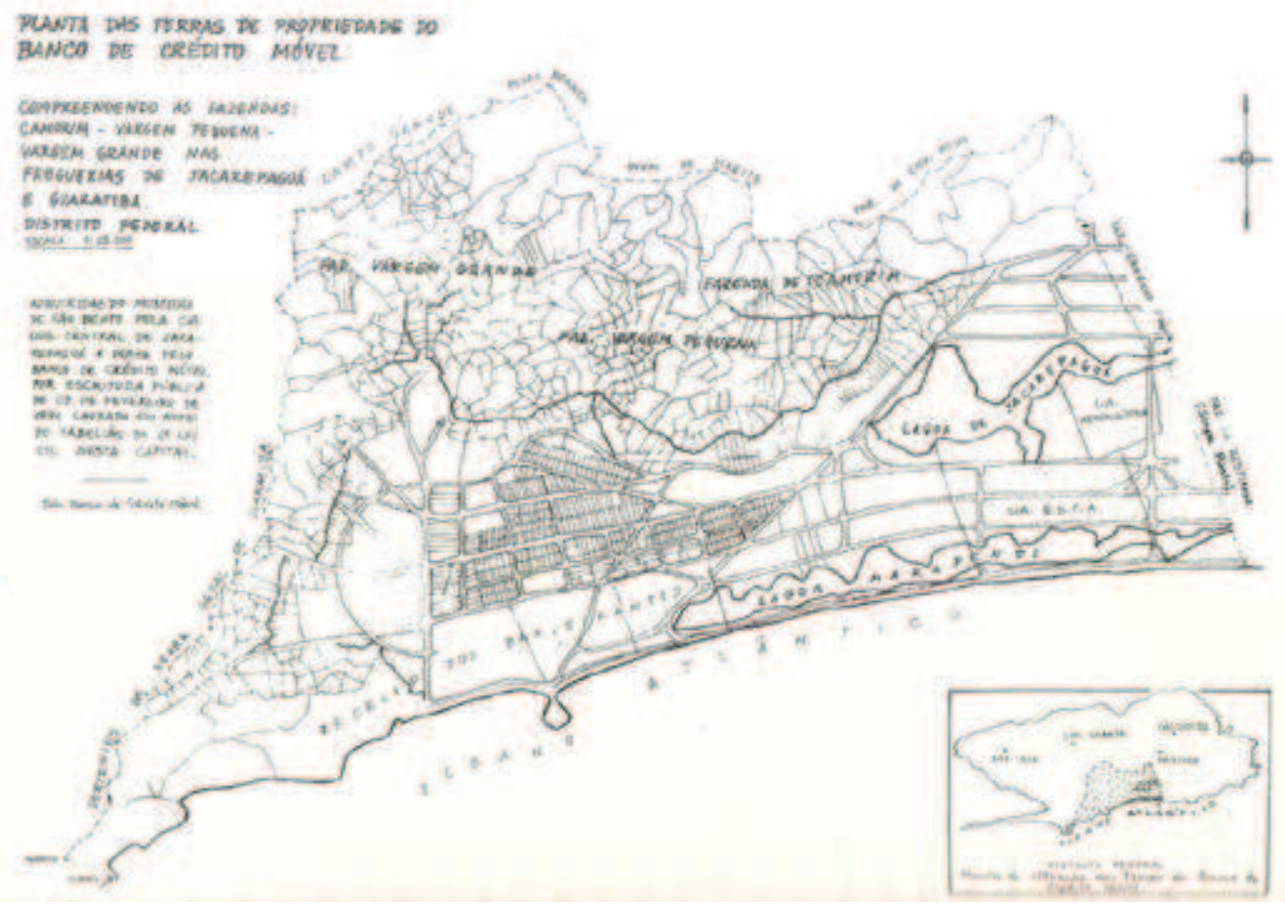

Figura 3 Planta de terras de propriedade do Banco de Crédito Móvel na primeira metade do século XX. Fonte: Fridman (1999, p. 136).

Apesar do aumento da atividade imobiliária na região, através de compra e venda de terras, o zoneamento proposto para a cidade em 1925 estabeleceu que a área fosse uma Zona Rural, o que limitou sua ocupação por novas edificações para fins especifi- 
camente agrícolas. Nessa época, a expansão da cidade concentrava-se nos subúrbios próximos ao centro, na zona sul e na zona norte. Em 1945, passou a ser permitido o desmembramento dos lotes em áreas mínimas de $10.000 \mathrm{~m}^{2}$ e testada de 50 metros lotes encontrados até os dias atuais. Em 1951, foi aprovado o Projeto de Alinhamento (PAA) n. 5.596 (figura 4), que traçou as novas diretrizes para vias arteriais na Planície de Jacarepaguá, e que foi base para o Plano elaborado por Lucio Costa em 1969.

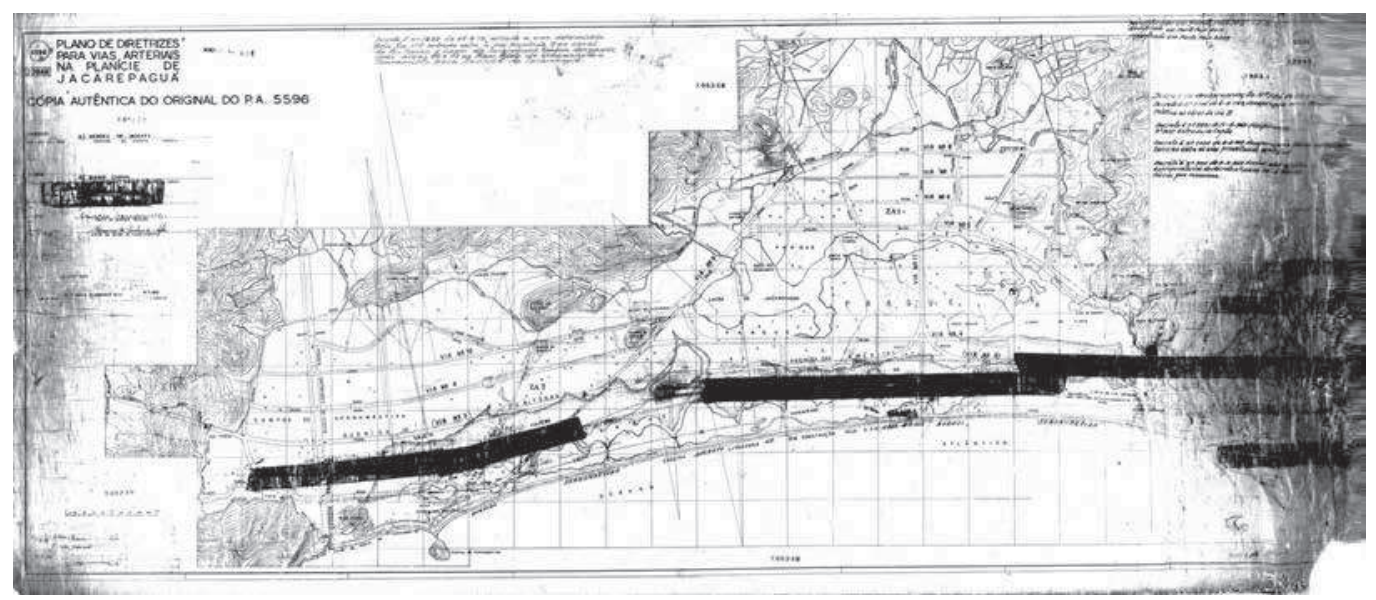

Figura 4 PAA n. 5.596.

Fonte: Prefeitura da Cidade do Rio de Janeiro - 1951

Disponível em: <http://www2.rio.ri.gov.br/smu/acervoimagens/principal.asp>.

Acesso em: 10 out. 2013.

Segundo Rita Montezuma (2010, p. 1), a região das Vargens, circundada pelos maciços da Pedra Branca e da Tijuca, é "[...] uma região recente do ponto de vista geológico [...], e a Baixada de Jacarepaguá é a única que ainda abriga alguns representantes dos ecossistemas próprios dessas áreas [...]" - tais como remanescentes florestais da mata atlântica. A autora demonstra como a região é ambientalmente frágil e suscetível ao provável adensamento urbano.

A figura 5 apresenta detalhe do mapa de bacias e sub-bacias hidrográficas da região das Vargens, e permite observar a grande quantidade de corpos hídricos e áreas sujeitas a alagamentos. Na figura 6 podemos ver um panorama geral da região, em que é visível a massa vegetal dos remanescentes florestais existentes.

O Plano do arquiteto Lucio Costa, elaborado para a Baixada de Jacarepaguá em 1969 (ilustrado na figura 7), determinou a divisão da região em 46 áreas. Os bairros de Camorim e Vargens, apesar da ocupação residencial existente na ocasião, foram descritos por Costa (1969, p. 13) como áreas a serem, preferencialmente, destinadas a "[...] finalidades que requeiram espaços abertos e ambientação [...]" - o que demonstra preocupação com a ocupação, tendo em vista sua condição ambiental. 


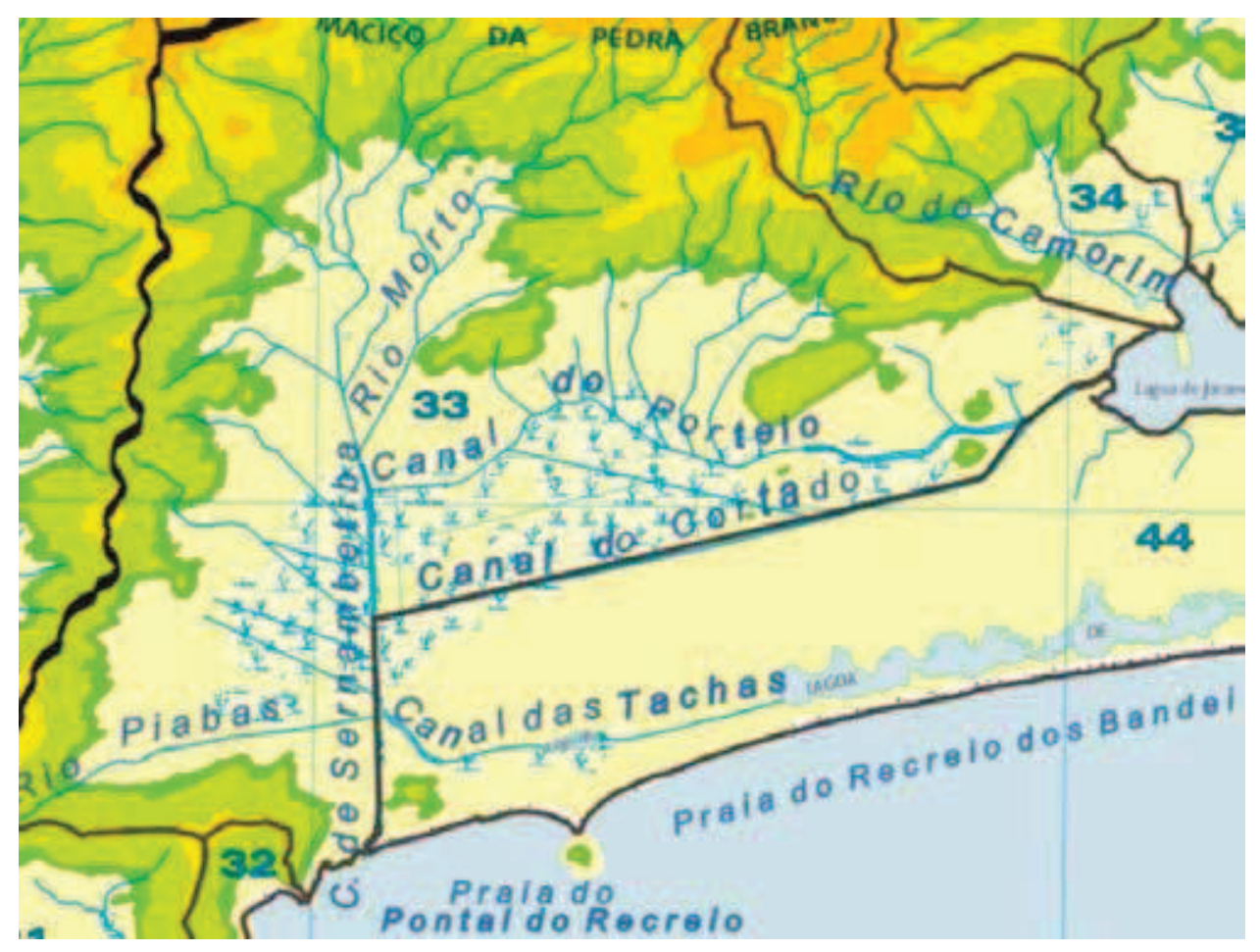

Figura 5 Detalhe do mapa de bacias e sub-bacias hidrográficas da região de Vargens. Fonte: Prefeitura da Cidade do Rio de Janeiro - 2004.

Disponível em: <http://www.armazemdedados.rio.ri.gov.br/>. Acesso em: 10 out. 2013.

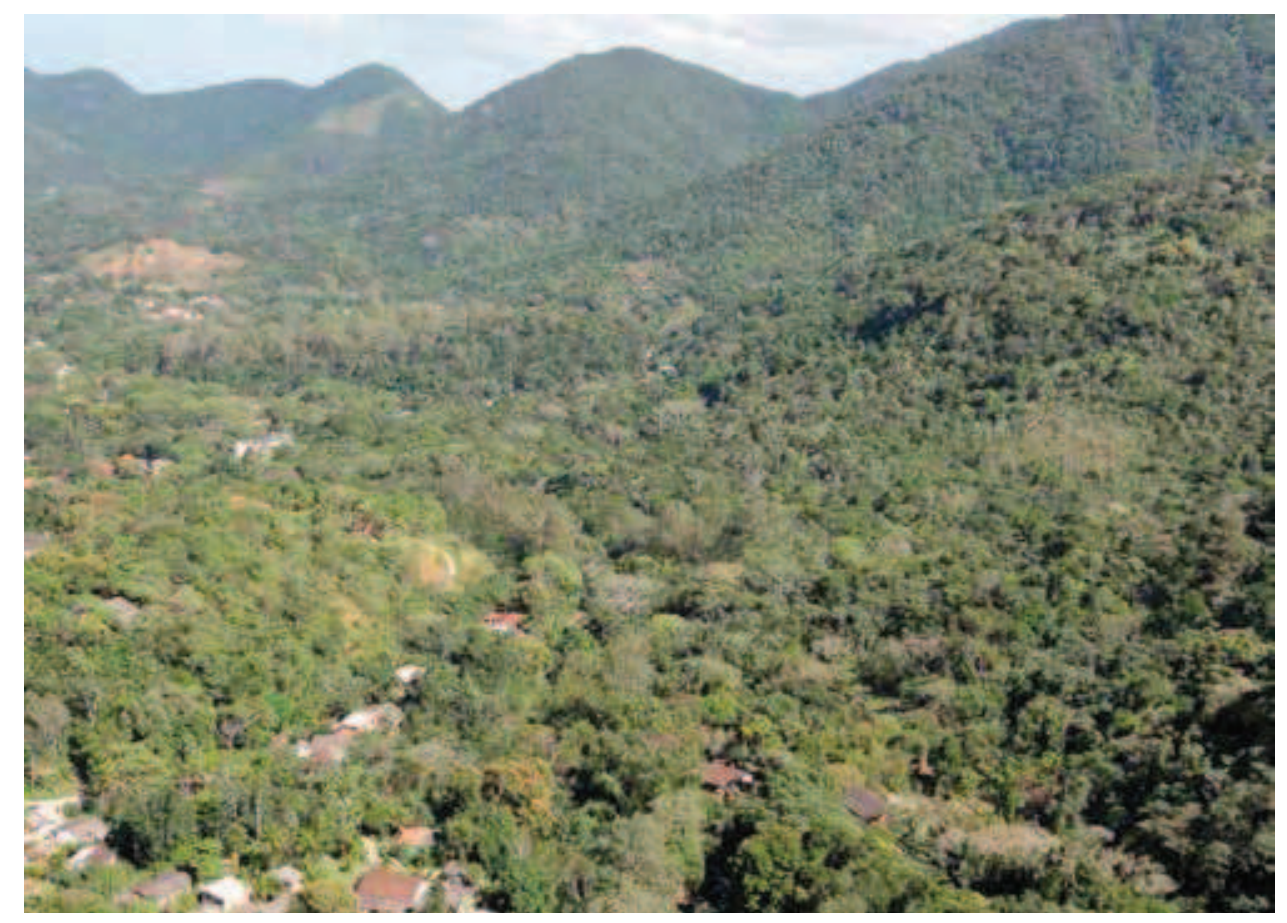

Figura 6 Panorama atual da cobertura florestal presente na região.

Fonte: SEL/RJ - 2011. 


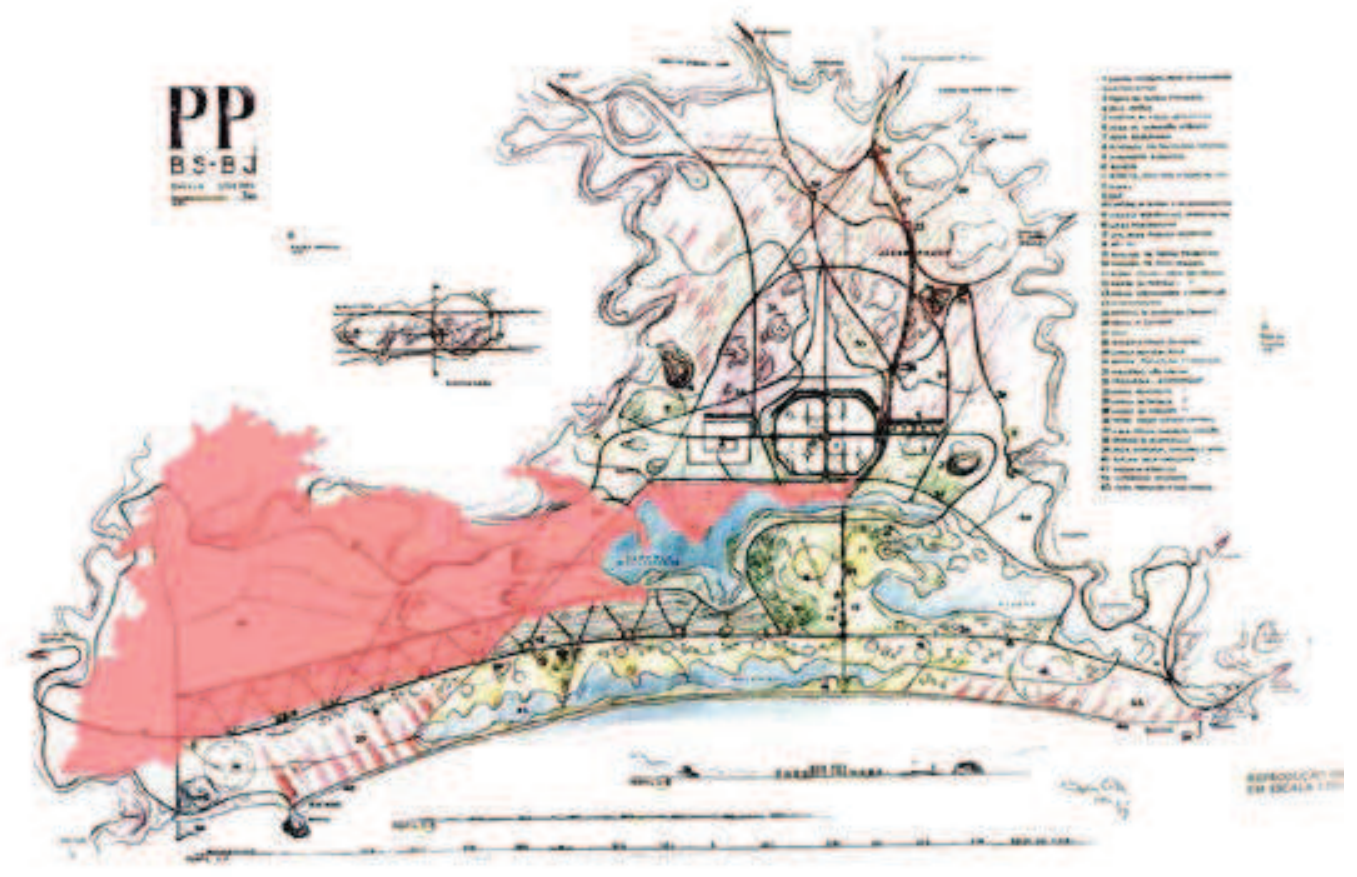

Figura 7 Plano Lucio Costa com a marcação do PEU das Vargens.

Fonte: Desenho elaborado por Rogerio Goldfeld Cardeman sobre croquis de Lucio Costa - 1969.

\section{O PLANO URBANÍSTICO BÁSICO DO RIO DE JANEIRO: PUB-Rio E CRIAÇÃO DO PROJETO DE ESTRUTURAÇÃO URBANA}

Em 1977 foi elaborado pela Secretaria de Planejamento e Coordenação Geral da Cidade do Rio de Janeiro e, exclusivamente, por técnicos da prefeitura, o Plano Urbanístico Básico (PUB-Rio), publicado em meio ao processo de extinção do Estado da Guanabara e fusão com o Estado do Rio de Janeiro. A cidade passou a pertencer ao Estado do Rio de Janeiro e a ser a sua capital.

O PUB-Rio (figura 8), diferentemente dos planos Agache e Doxiadis, não buscou um modelo ideal, limitando-se a um plano de diretrizes que permitissem, através de uma estrutura espacial, fortalecer a posição da cidade na Região Metropolitana e nas economias regional e nacional. (REZENDE, 1982). 


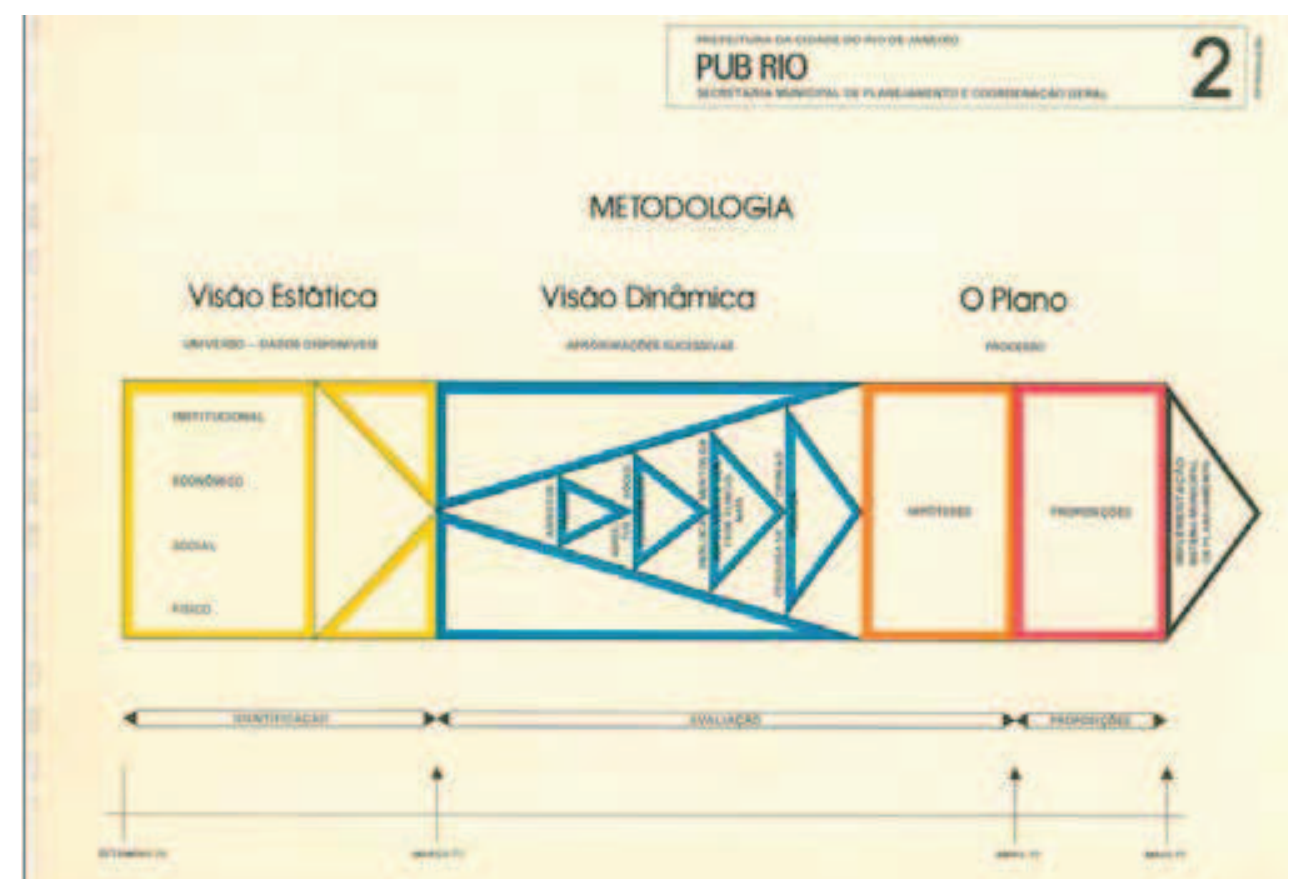

Figura 8 Gráfico com a metodologia adotada para elaboração do Plano. Fonte: PUB-Rio - 1977.

Após diversas pesquisas e análises do território da cidade e de sua dinâmica urbana, esse plano propôs a sua divisão em seis Áreas de Planejamento (AP's), subdivididas em 55 Unidades Especiais de Planejamento (UEP's), onde cada unidade correspondia a um ou mais bairros (PUB-Rio, 1977), (figura 9).

Segundo o arquiteto Armando Abreu (2012), coordenador do Plano, após análise do território da cidade, concluiu-se que não havia uma homogeneidade no perfil do território e em suas características. Em face disso, a divisão em UEP's tinha como intenção agrupar as diversas unidades territoriais de acordo com suas características morfológicas e ambientais. Os parâmetros surgidos com o plano visavam ao adensamento das áreas já consolidadas, aproveitando ao máximo a infraestrutura existente.

O item implementação especificado no Plano orientou como o mesmo deve ser implantado e gerido. São identificados problemas na estrutura de governo, sugerindo-se a criação de uma Secretaria de Desenvolvimento Urbano que estivesse, na hierarquia de governo, acima das outras pastas e que pudesse tomar decisões tanto globais como locais, o que garantiria uma coordenação integrada na gestão da cidade. Outro aspecto abordado pelo plano é a viabilidade financeira. Deveriam ser garantidos recursos para a implementação das propostas elaboradas a fim de que o plano não virasse apenas documentos utópicos (REZENDE, 1982).

No Decreto que aprovou o PUB-Rio, um artigo determina que o detalhamento e a atualização do Plano devem ser feitos através dos Projetos de Estruturação Urbana (PEU's), nos quais seriam estudados novos parâmetros urbanos para cada unidade, abordando características específicas de cada uma. Segundo Armando Abreu, as áreas 
objeto destes projetos não necessariamente seriam bairros ou UEP's, e sim áreas que tivessem características próximas (figura 10).

PUB RIO 40

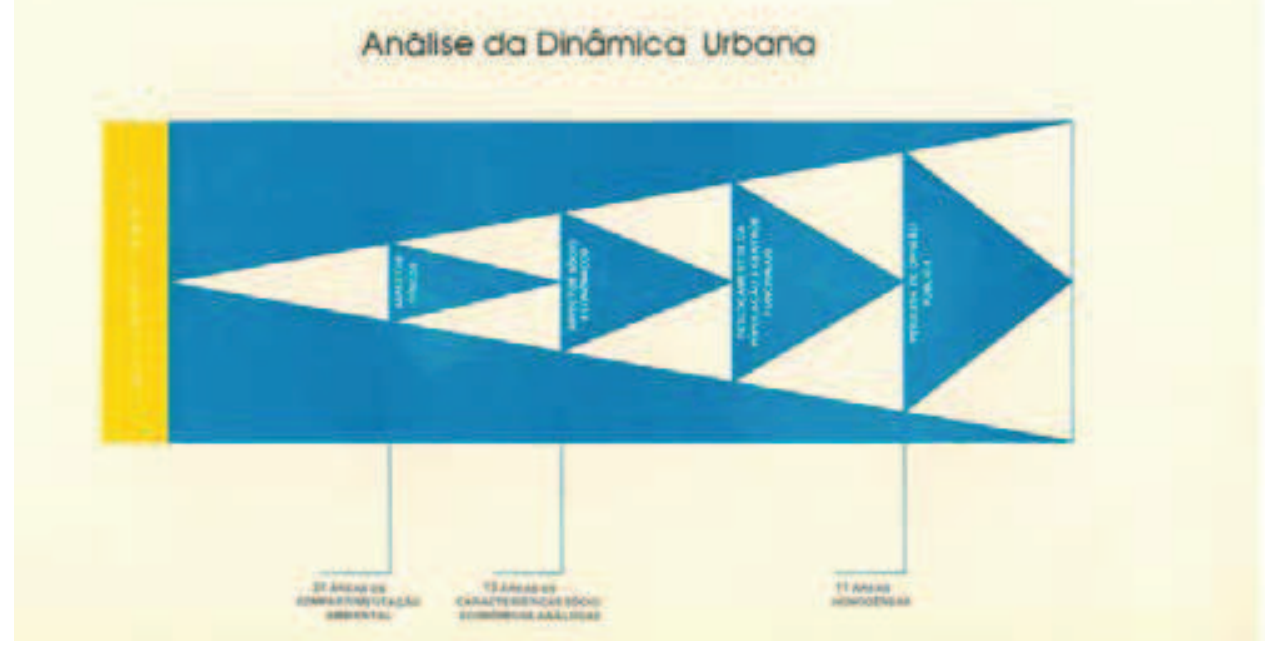

Figura 9 Análise da dinâmica urbana que auxiliou na criação das seis Áreas de Planejamento. Fonte: PUB-Rio - 1977.

Entretanto, mesmo sendo planejados por partes, os PEU's deveriam se inserir em uma visão geral e integrada da cidade, e também relacionar-se à Região Metropolitana. A intenção dos PEU's era tratar tanto de legislação quanto de desenho urbano, sendo o estudo da morfologia do território ponto fundamental para o sucesso dos projetos.

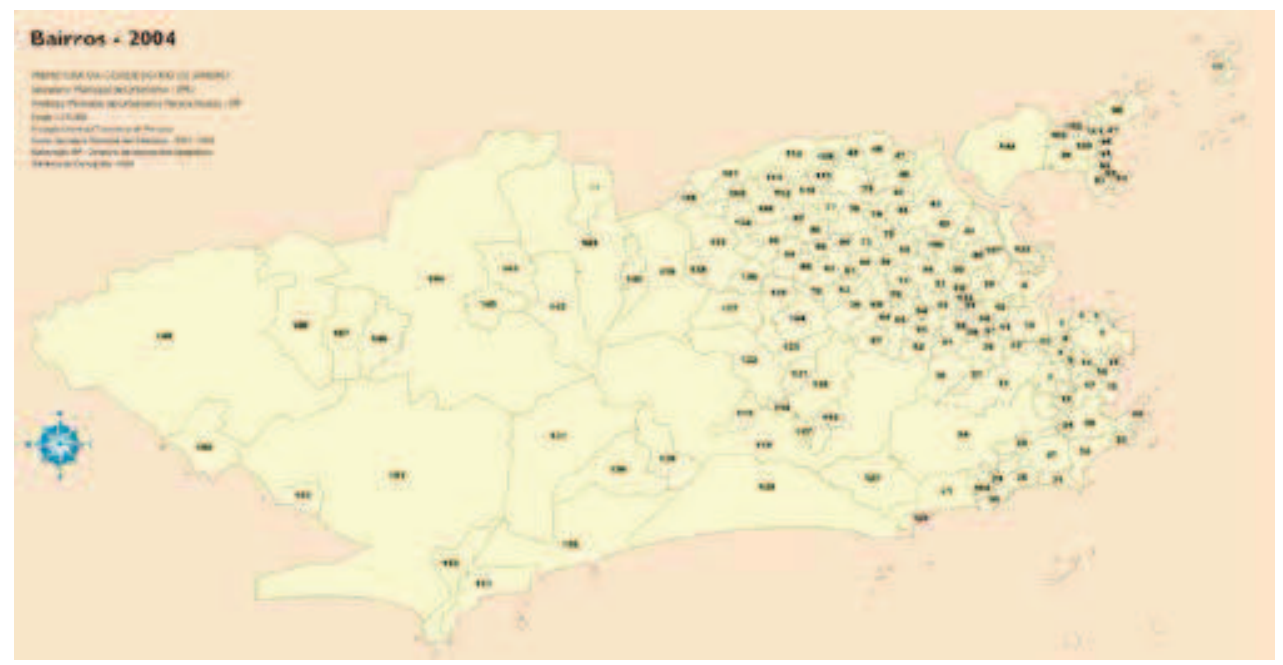

Figura 10 Mapa com a divisão dos bairros.

Fonte: Prefeitura da Cidade do Rio de Janeiro - 2004. 
Além de parâmetros urbanísticos, nos PEU's deveriam ser estudados os sistemas viários, como novos alinhamentos e ruas, e os sistemas de transporte e infraestrutura, o que nunca foi feito, pois os planos só abordaram a questão dos parâmetros urbanísticos. Cabe destacar que o PUB-Rio foi feito sob uma ótica do planejamento que visava ao desenvolvimento econômico baseado na indústria - e é a partir deste período que ocorreu um grande fluxo migratório para a cidade e para a Região Metropolitana.

Desde 1978 foram aprovados os PEU's para Urca, Andaraí, Maracanã e Vila Isabel (figura 11), Botafogo e Leblon. Cabe ressaltar que alguns dos decretos não traziam em seu corpo o nome Projeto de Estruturação Urbana, mas como apresentavam a estrutura característica de um PEU e eram elaborados pelo município sempre foram chamados desta forma.

Vale colocar que nenhum estudo sobre sistema e impactos viários ou reordenamento fundiário foi proposto em conjunto com os PEU's, apesar de previsto no PUB-Rio. Além disso, os projetos apresentavam apenas um mapa de zoneamento e gabarito e, basicamente, eram compostos por diversos artigos que determinavam parâmetros sem demonstrar graficamente sua intenção.

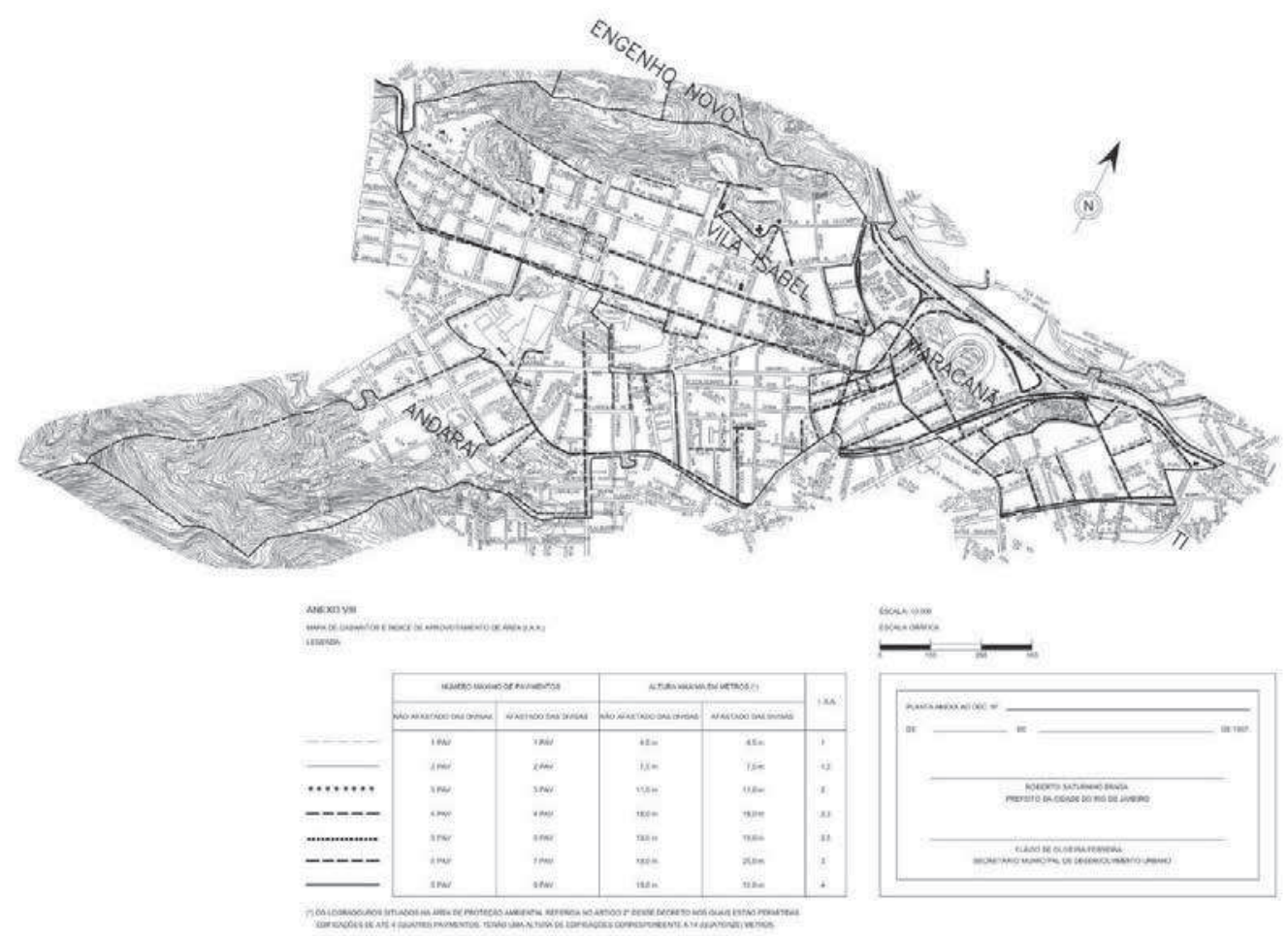

Figura 11 Mapa contido no PEU para Andaraí, Vila Isabel e Maracanã. Fonte: Prefeitura da Cidade do Rio de Janeiro - 1987. 
Flavio Villaça (1999, p. 219) denomina esta fase do planejamento urbano no Brasil de "Planos sem Mapa". Ele descreve que os planos passaram a ser feitos de forma simplória pelos próprios técnicos locais e quase sem a presença de mapas e diagnósticos reduzidos e apresentando apenas objetivos, políticas e diretrizes. "Seus dispositivos são um conjunto de generalidades. Novamente, o plano inconsequente."

Durante os vinte anos que sucederam a promulgação do PUB-Rio, houve grande ocupação em priorizar investimentos voltados às classes média e alta das áreas formais da zona sul da cidade. Enquanto isso, com a falta de financiamento para habitação popular, as dificuldades de acesso à propriedade da terra urbana por setores de baixa renda, o fechamento do Banco Nacional da Habitação e o pouco investimento em transportes de massa, as ocupações informais aumentaram de forma rápida em direção às áreas ambientalmente frágeis ou de pouco interesse para mercado imobiliário, como APP's e encostas íngremes.

Na década de 2000, novos PEU's foram sancionados, como os de Campo Grande, Taquara, Tanque e Freguesia, na zona oeste, São Cristovão e o do entorno do Estádio do Engenhão, na zona norte. Com parâmetros urbanísticos mais atraentes ao mercado imobiliário e com a saturação dos terrenos para edificação na zona sul, essas regiões começaram a ser objeto de interesse por parte do setor.

No final de 2009, novas leis para bairros ou regiões específicas da cidade foram aprovadas, motivadas pela escolha da cidade como sede da Copa do Mundo de Futebol de 2014 e dos Jogos Olímpicos de 2016. Essas leis incluíram as regiões de Vargem Grande e Vargem Pequena e a Área Portuária. Ainda é difícil avaliar o impacto destas novas posturas urbanas na paisagem da cidade, mas é provável que seja objeto de grande interesse para o mercado imobiliário.

\section{O PROJETO DE ESTRUTURAÇÃO URBANA DAS VARGENS}

O PEU das Vargens foi aprovado pela Lei Complementar № 104 de 2009 (figuras 12 a 14) - cinco anos após ter sido encaminhado pela primeira vez à Câmara de Vereadores - e trata do Projeto de Estruturação Urbana para os bairros de Vargem Grande, Vargem Pequena, Camorim e parte dos bairros Recreio dos Bandeirantes, Barra da Tijuca e Jacarepaguá, nas XXIV e XVI Regiões Administrativas, integrantes das Unidades Espaciais de Planejamento números 40, 45, 46 e 47. Anteriormente a essa lei, a área pertencia à Zona Especial 5 (ZE-5), que era regulada pelas normas urbanas decorrentes do Plano Lucio Costa de 1969.

O Projeto apresentado tem em seus primeiros parágrafos vários objetivos a serem alcançados por meio da implantação da proposta. Dentre eles, destacam-se: orientar a ocupação urbana da área condicionando-a à proteção do meio ambiente e às suas características paisagísticas e de fragilidade ambiental; promover relação adequada entre adensamento e possibilidades do sítio; adequar os parâmetros urbanísticos à realidade local; tornar mais eficaz o seu controle em virtude da intensificação da ocupação urbana e do crescente surgimento de loteamentos irregulares e clandestinos. 


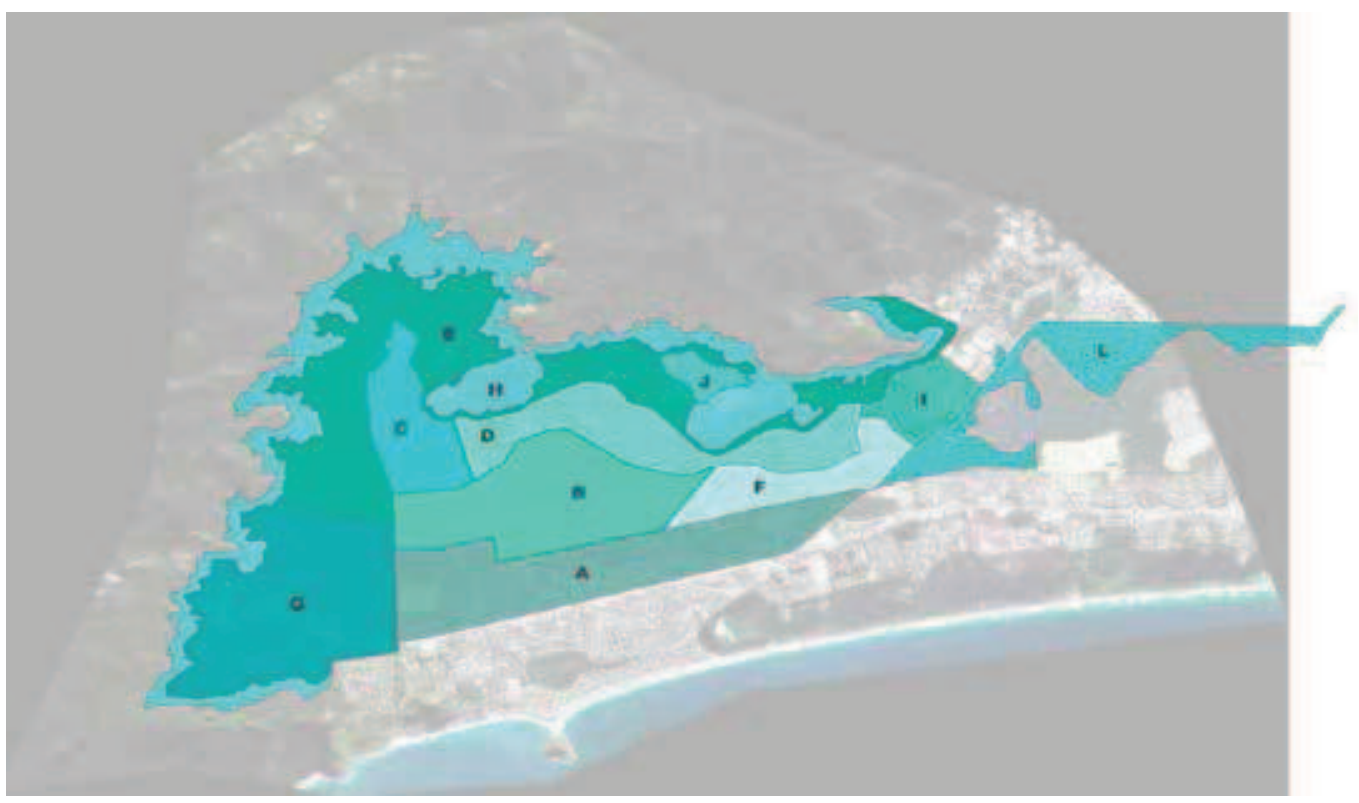

Figura 12 Divisão dos setores do PEU das Vargens.

Fonte: Arquivo SEL-RJ. Com base na Lei № 104, de 2009.

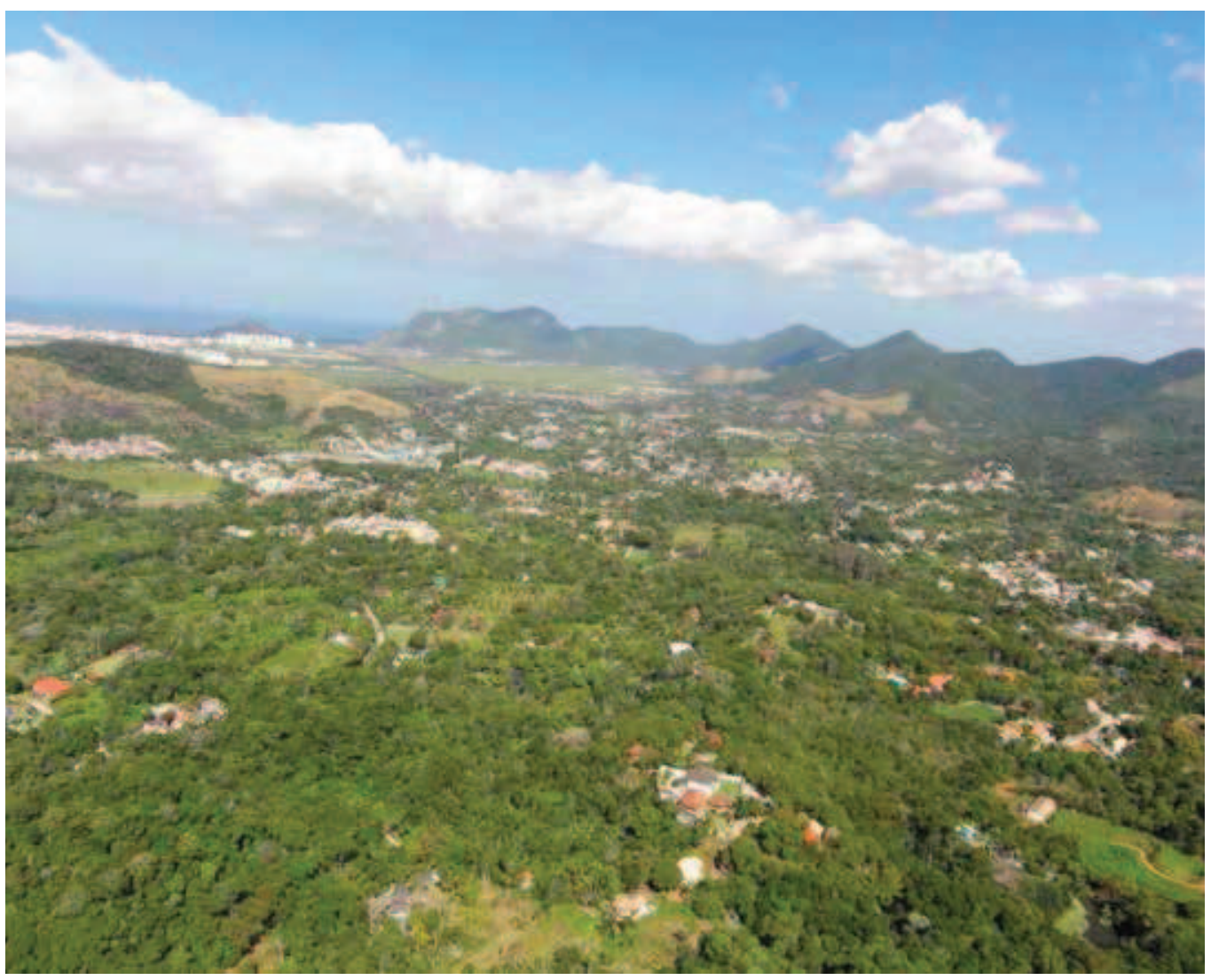

Figura 13 Predominância de áreas verdes na região de Vargens.

Fonte: SEL/RJ - 2011 


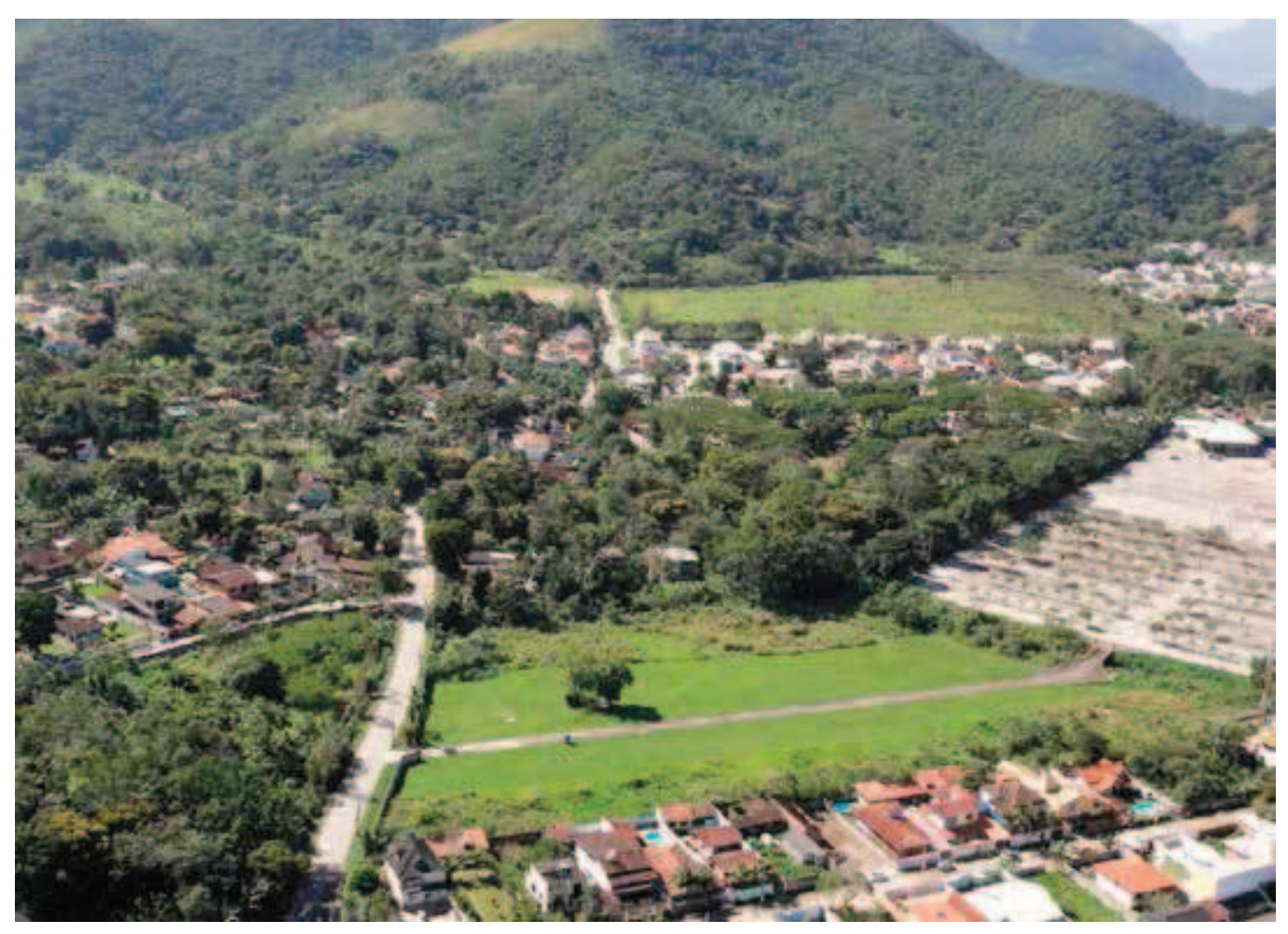

Figura 14 Grandes áreas verdes se misturam com loteamentos irregulares. Fonte: SEL/RJ - 2011.

A lei determina como diretrizes básicas: proteger o meio ambiente e a paisagem local; complementação e implementação do sistema viário projetado com enfoque na melhoria da mobilidade através de transporte de massa; utilização de instrumentos que possam arrecadar recursos para novos investimentos; conter a ocupação irregular na região; manutenção da atividade agrícola remanescente. Ainda na parte das premissas, no artigo 15 a criação do PEU é condicionada à ocupação e proteção da paisagem natural do sítio.

Projeto divide a área em 11 setores. Na Zona Residencial Unifamiliar (ZRU), permitem-se residências ou grupamentos unifamiliares além de edificações destinadas a serviços. Nas Zonas Residenciais Multifamiliares (ZRM), além do descrito em ZRU, permitem-se edificações destinadas a serviços e uso multifamiliar. As Zonas de Uso Misto (ZUM) abrangem todas as tipologias e se dividem em três tipos: desde a residencial uni e multifamiliar até a comercial de grande porte. Os Índices de Aproveitamento do Terreno (IAT)2 aprovados são variados e vão de 0.4 , sem contrapartida, a $3 \mathrm{com}$ contrapartida ${ }^{3}$, com gabaritos de 3 a 18 pisos. Esses índices estão bem acima dos anteriormente propostos pelo decreto que regulamentou o Plano Lucio Costa.

\footnotetext{
2 O IAT determina a densidade máxima permitida para cada área. O ATE é resultado da multiplicação do IAT pela área do terreno.

3 Contrapartida é o valor pago para a utilização dos índices acima do básico. Esse instrumento, conhecido como Outorga Onerosa do Direito de Construir, foi estabelecido pelo Estatuto das Cidades em 2001.
} 
Um dado interessante da proposta é que o PEU das Vargens, apesar do nome, não tem como objeto de regulação somente a área das Vargens e Camorim. Foram incluídas algumas áreas antes reguladas pelo Plano Lucio Costa, como o bairro do Recreio dos Bandeirantes. $\bigcirc$ que mais chama atenção nessa inclusão é que tais áreas se encontram em pontos muito valorizados, como os dois lados da avenida das Américas, principal eixo comercial da região, além do terreno onde está sendo construída a Vila Olímpica para os Jogos Olímpicos de 2016.

Nesses setores a construção de edifícios multifamiliares era bem restrita e, em alguns casos, nem era permitida, sendo que passaram a ter um novo zoneamento, que valoriza esses lotes, conforme demonstra a figura 15.

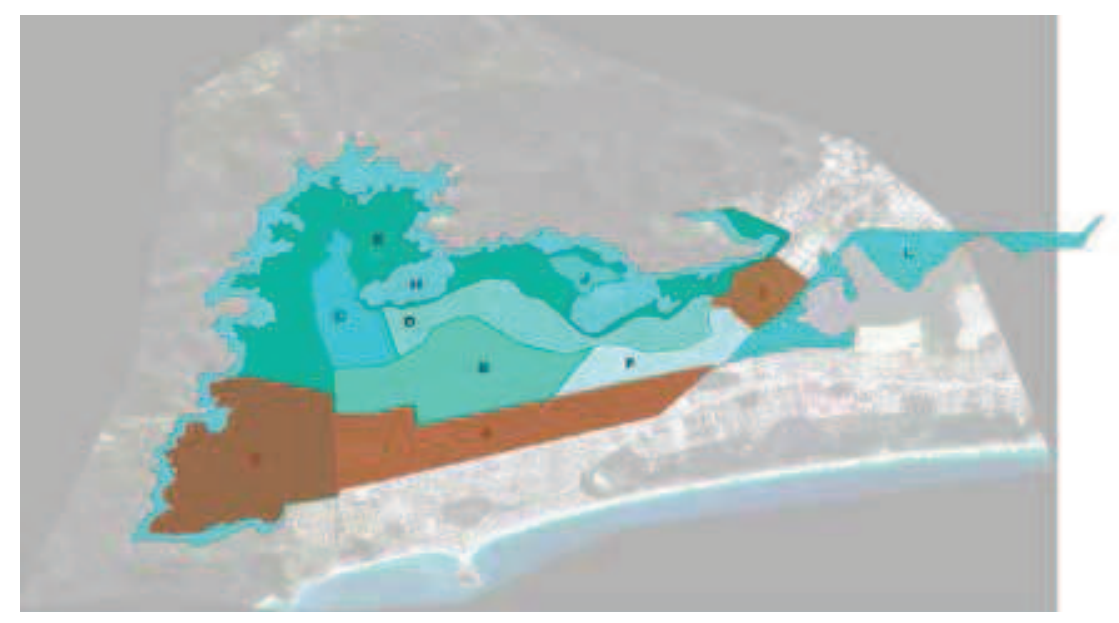

Figura 15 Áreas que ganharam valor com o PEU. Fonte: SEL-RJ. Com base na Lei № 104, de 2009.

\section{MAPA DE ZONEAMENTO DO PEU VARGENS}

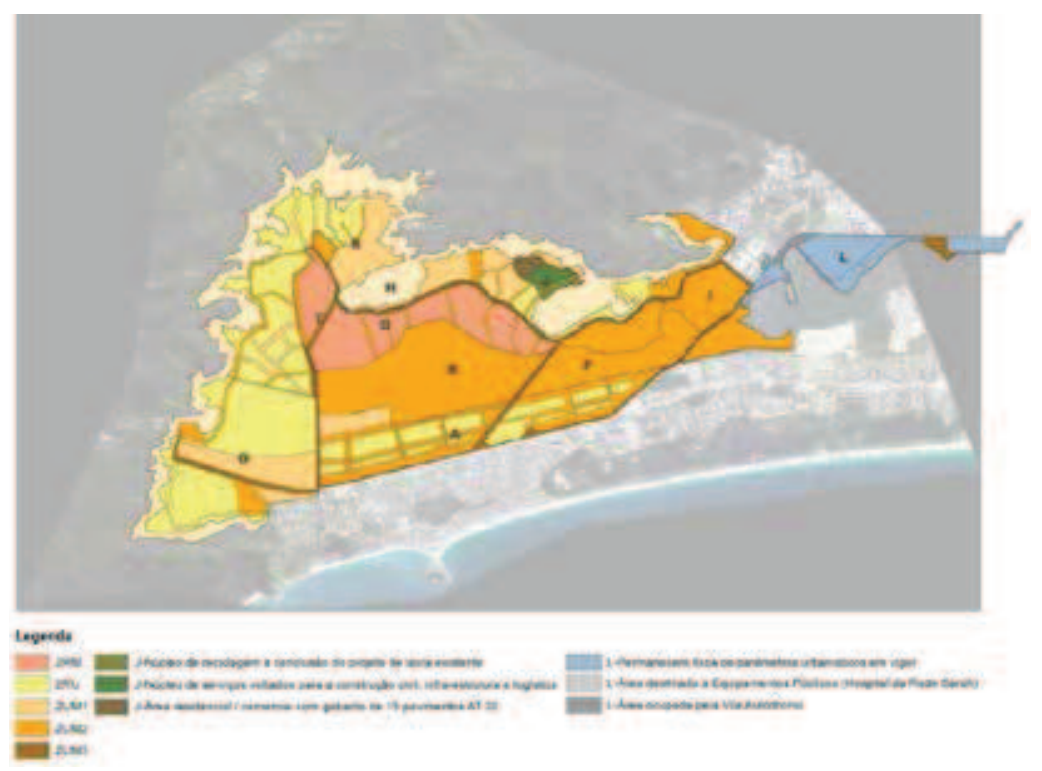

Fonte: Arquivo NIPP. Com base na Lei № 104, de 2009. 


\section{QUADRO DE USO E OCUPAÇÃO DOS SETORES DO PEU VARGENS E SEUS EXEMPLOS}

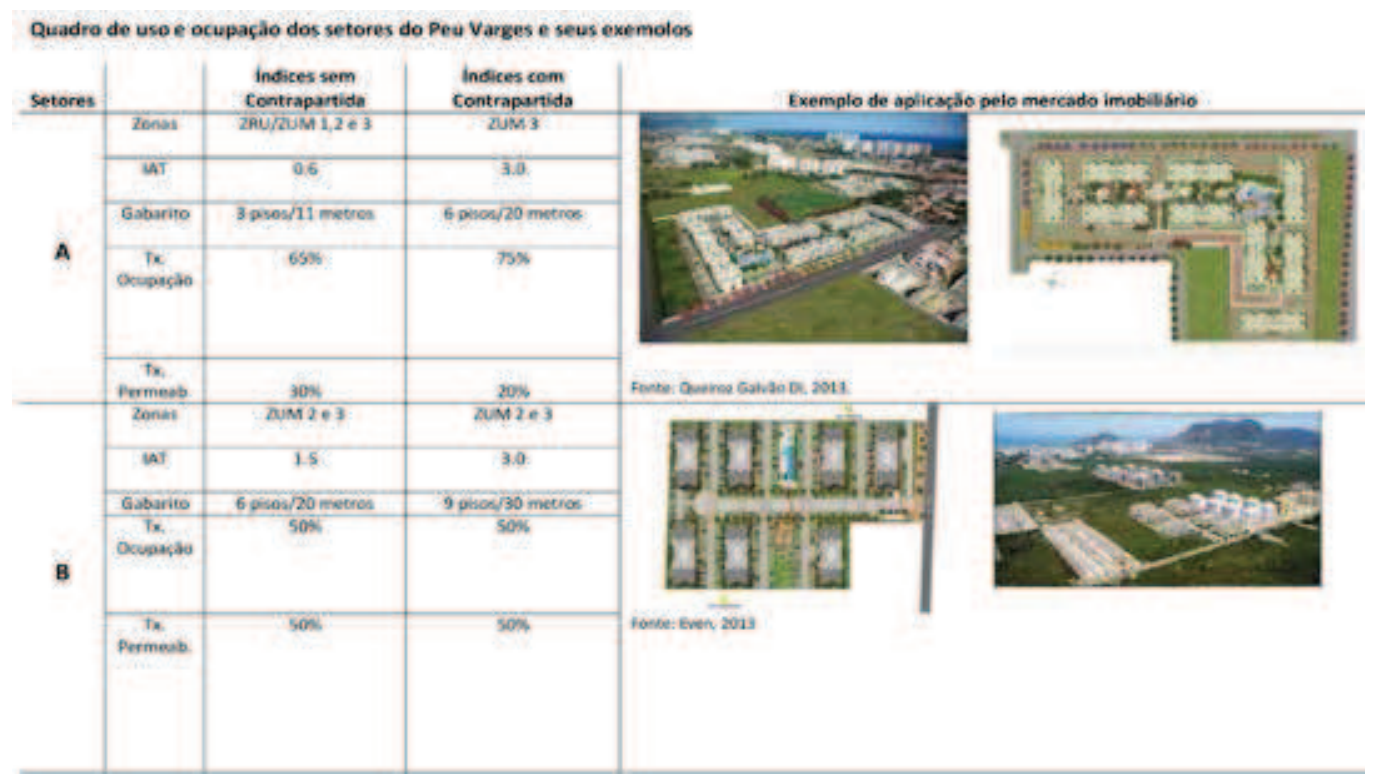

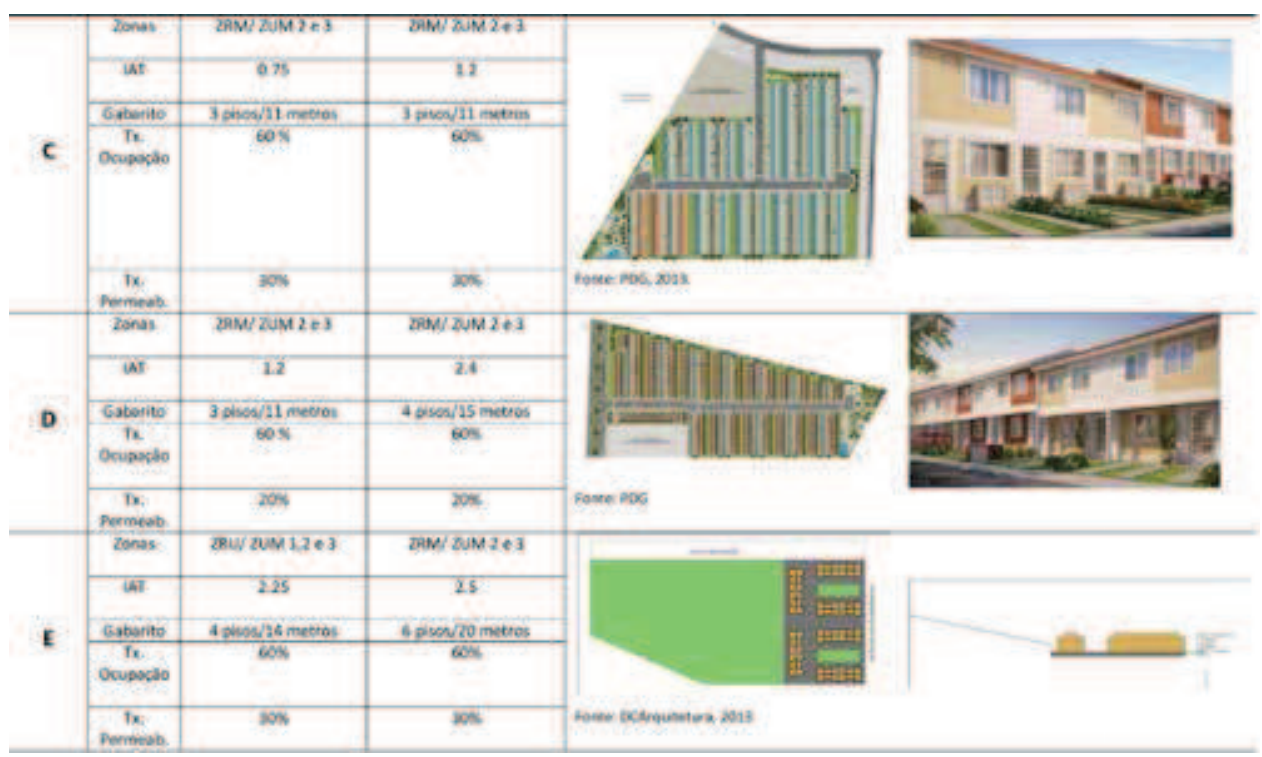



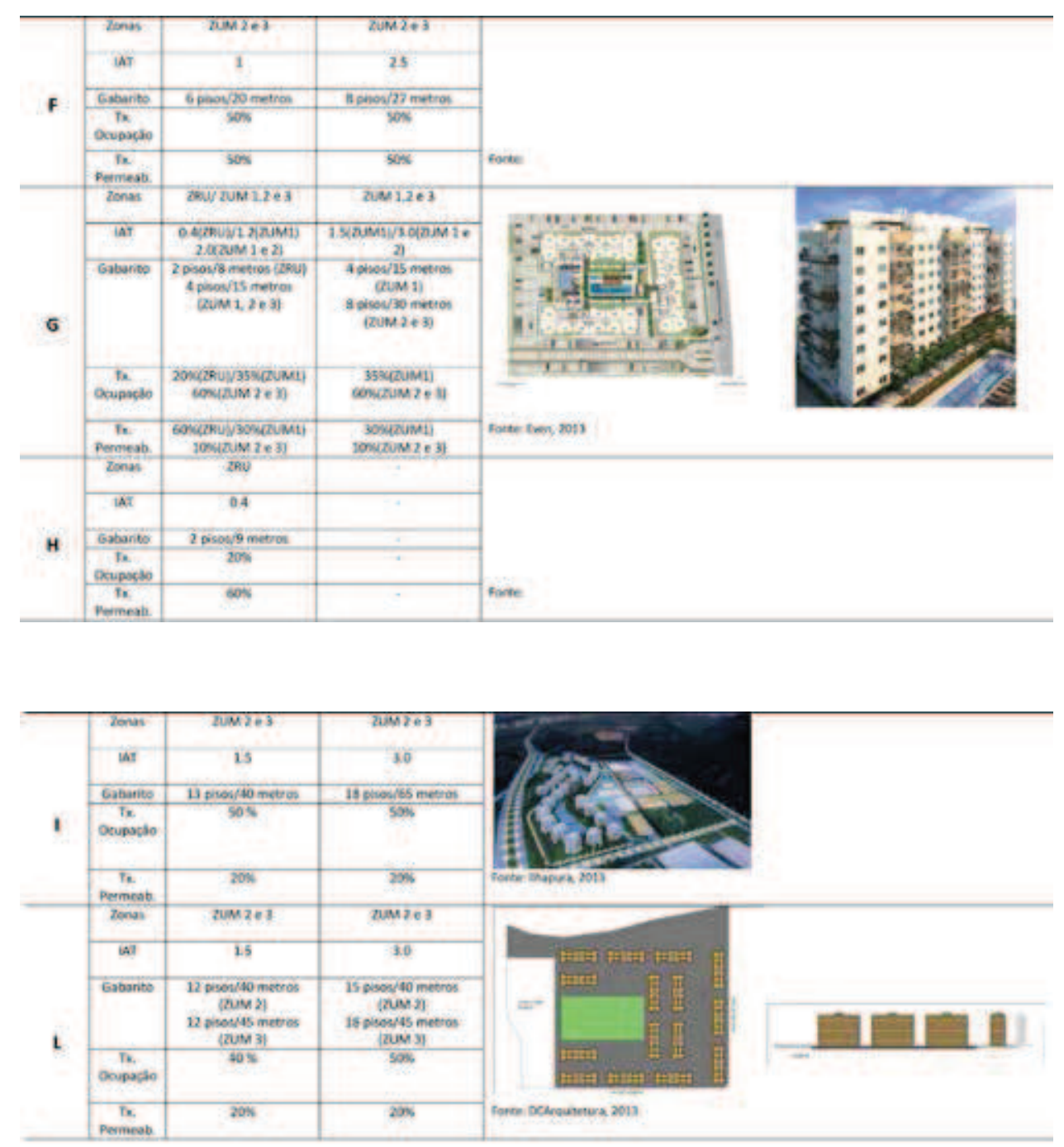

Fonte: Rogerio Goldfeld Cardeman - 2012.

Para Leonardo Name (2010), as mudanças urbanísticas propostas pelo PEU desconsideram a infraestrutura local e as condições ambientais. Mesmo a implantação da infraestrutura necessária para absorver essa nova ocupação pode ser prejudicial às condições ambientalmente frágeis da área, o que acarretará gastos elevados tanto para preservar as condições quanto para reverter os processos de danos ambientais.

Outro aspecto da lei é a permissão de adensamento maior em algumas áreas mediante o pagamento de Contrapartida (Outorga Onerosa do Direito de Construir). Além de permitir maior densificação da área, segundo Andrea Redondo, não ficou determinado na lei que os recursos provenientes da contrapartida deveriam ser revertidos para investimentos na própria região, garantindo assim o desenvolvimento da infraestrutura e preservação ambiental necessárias. (REDONDO, 2009). 
Duas situações chamam atenção neste momento da pesquisa. Após sobrevoo e trabalhos de campo na região, fica evidente, em primeiro lugar, a intensa ocupação em curso em praticamente todos os setores. A segunda situação é a maneira como passam a se dar as relações entre os espaços livres públicos e privados e entre esses e os espaços construídos (figuras 16 a 21).

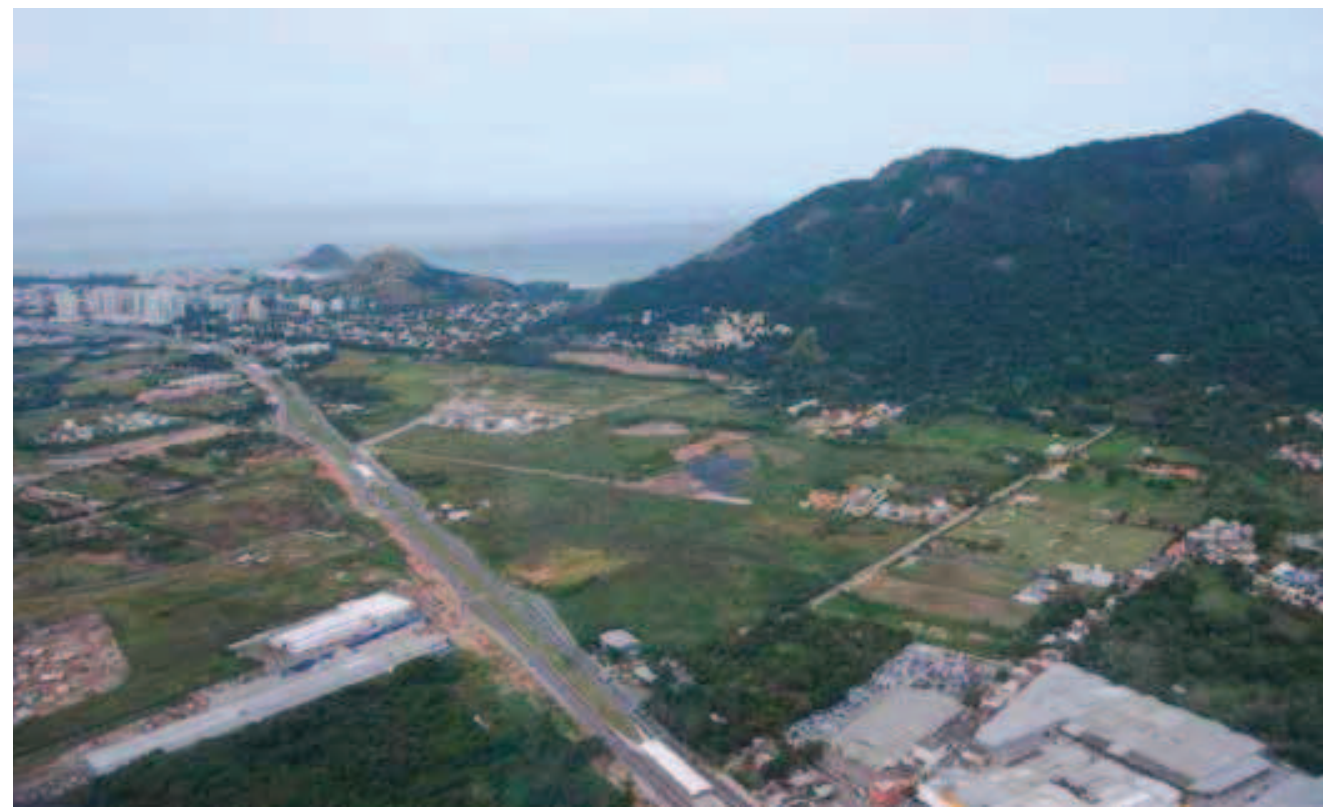

Figura 16 Vista aérea da Região das Vargens no setor que deverá sofrer grande transformação. Fonte: SEL/RJ - 2013

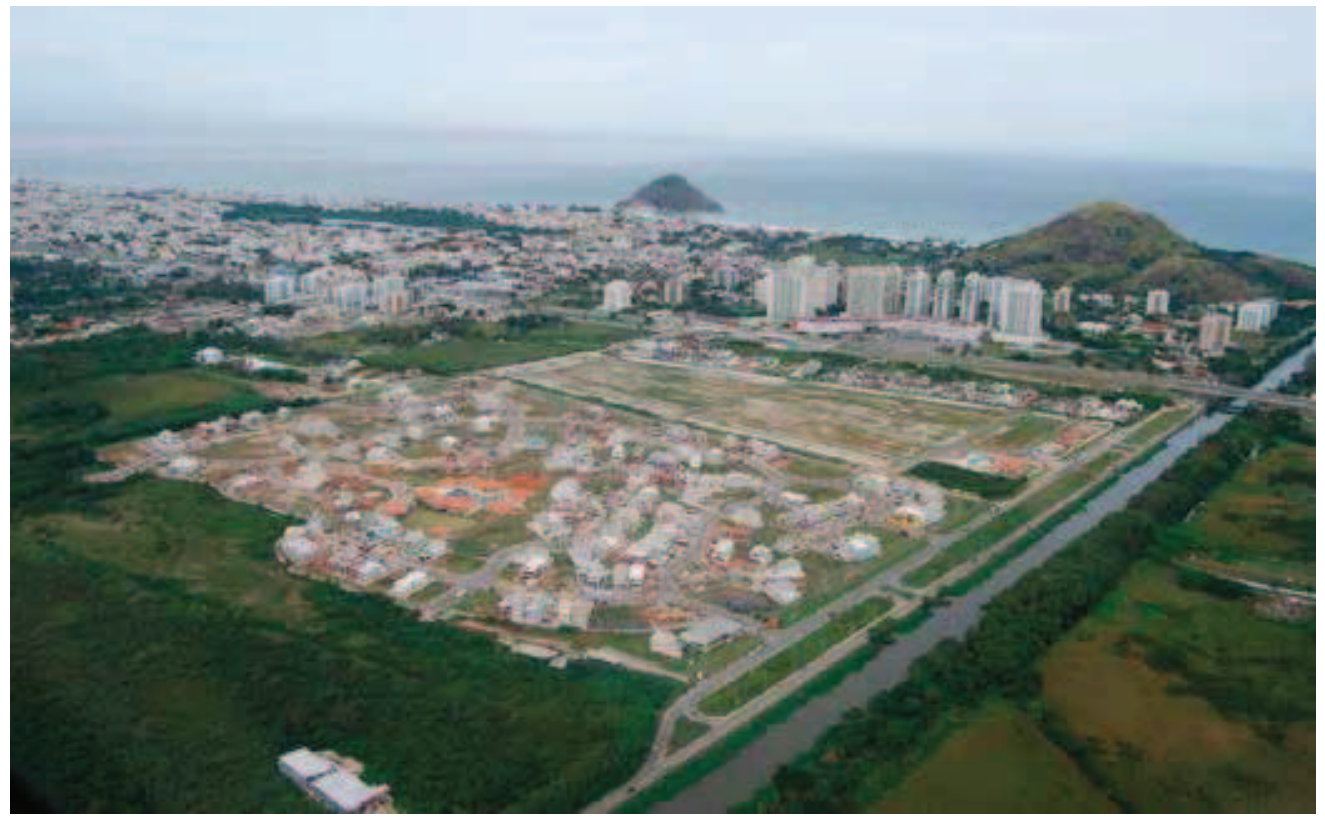

Figura 17 Vista aérea da Região das Vargens. Novas construções aparecem na Estrada Alceu de Carvalho, um dos eixos de maior valorização na região.

Fonte: SEL/RJ - 2013. 


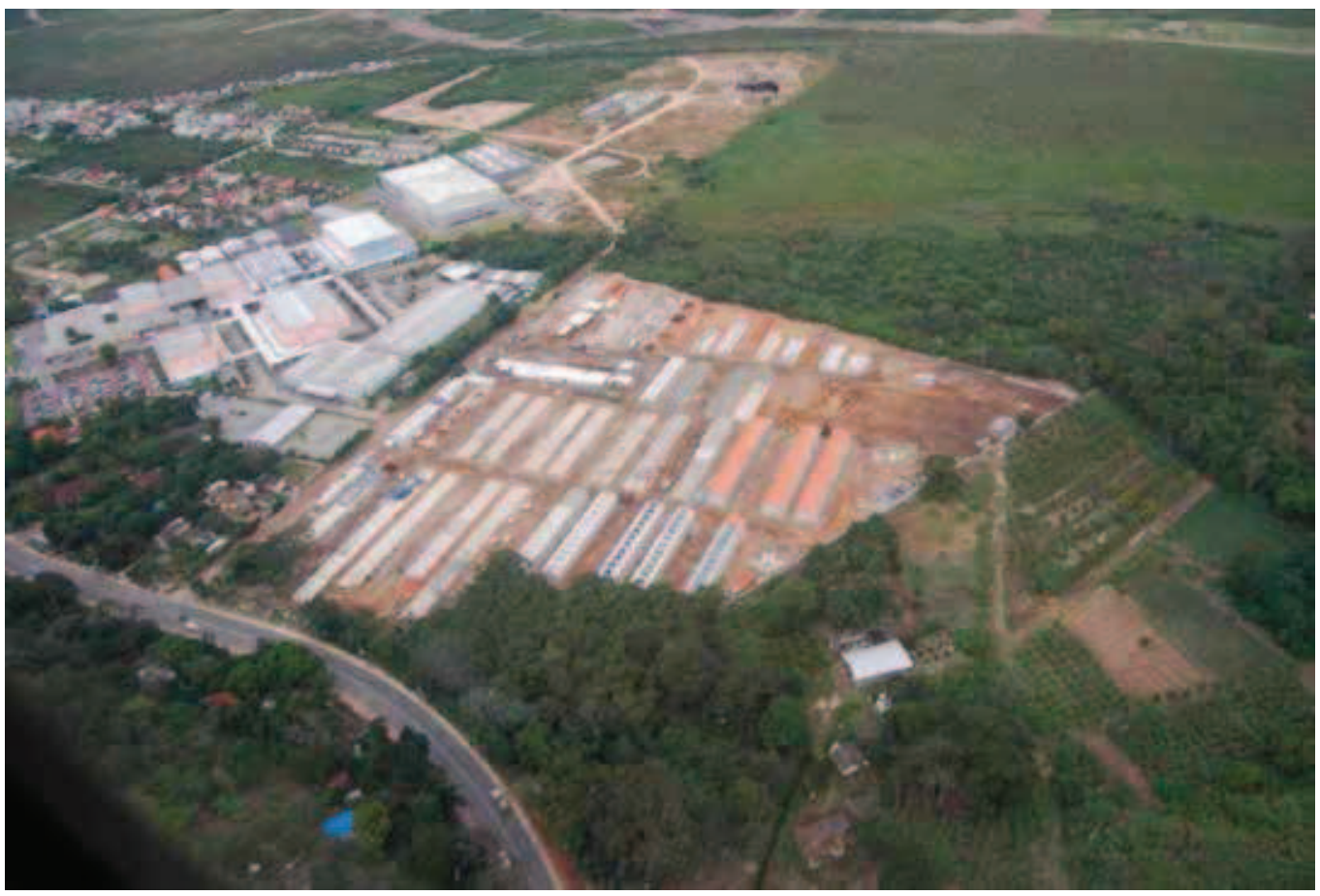

Figura 18 Vista aérea da Região das Vargens. Condomínio de casas geminadas na Estrada dos Bandeirantes. Fonte: SEL/RJ - 2013.

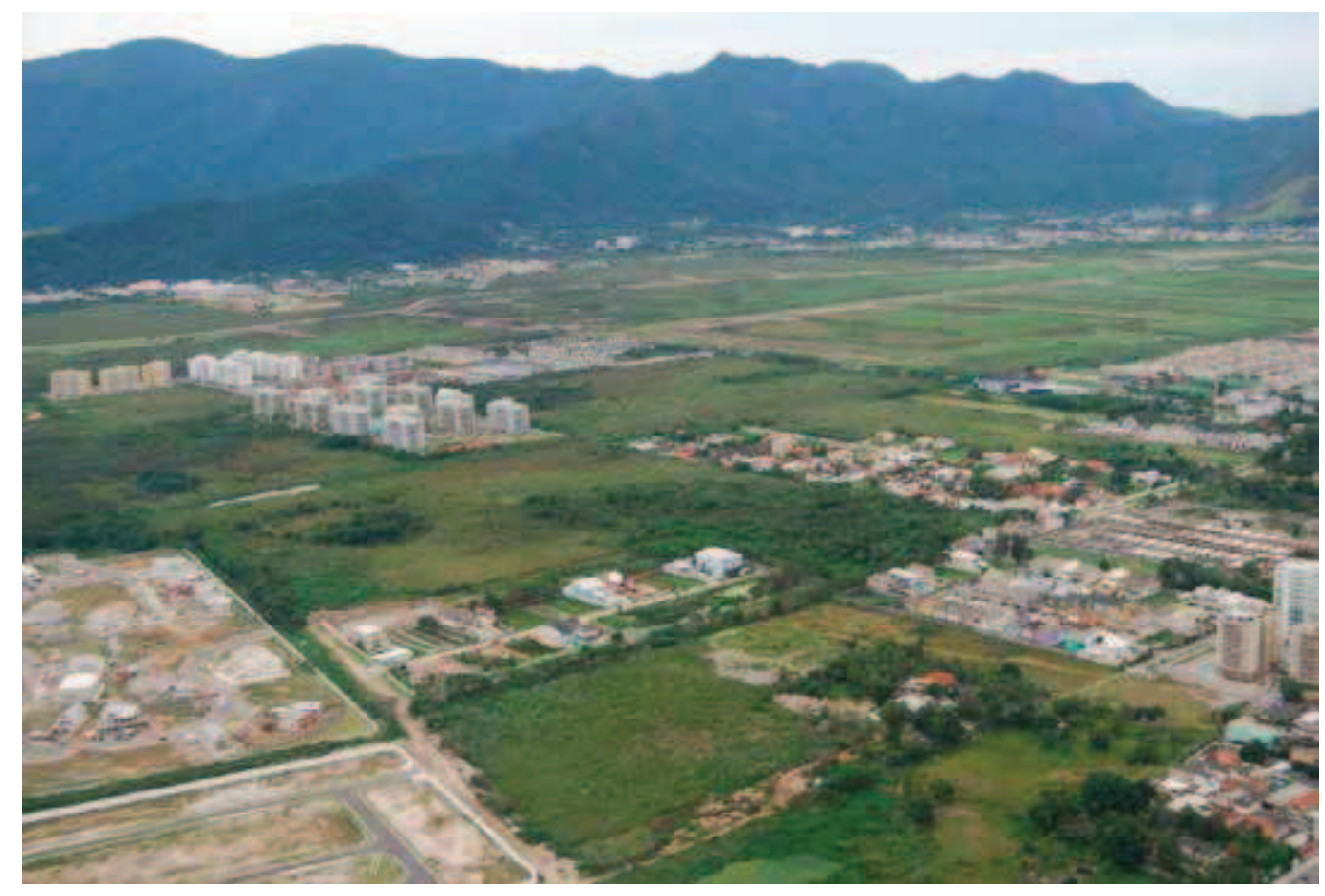

Figura 19 Vista aérea da Região das Vargens. A paisagem tipicamente agrícola vai sumindo rapidamente. Fonte: SEL/RJ - 2013 


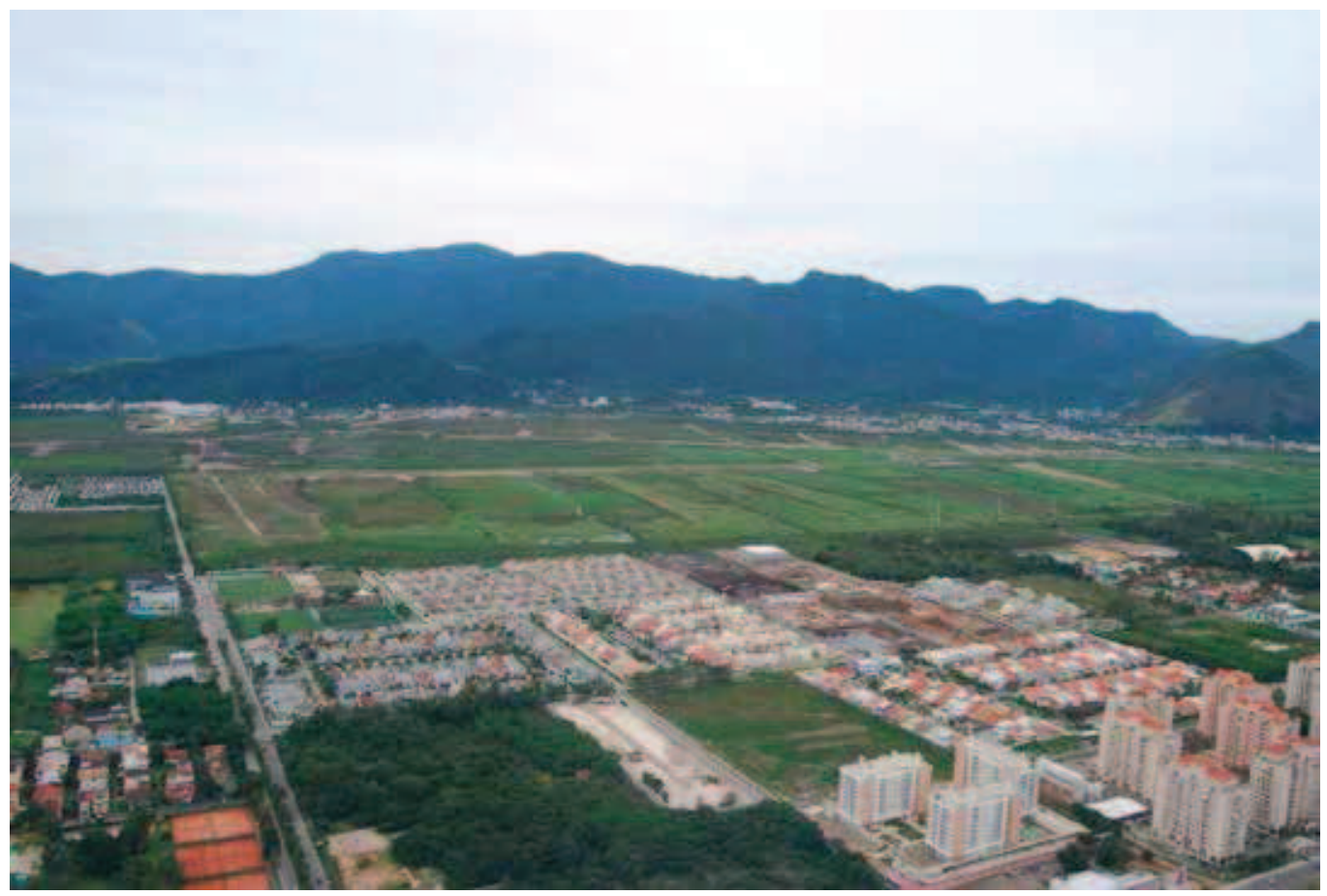

Figura 20 Vista aérea da Região das Vargens. Na área verde mais ao fundo está previsto um condomínio com uma grande área alagada, conhecida como "Veneza carioca".

Fonte: SEL/RJ - 2013.

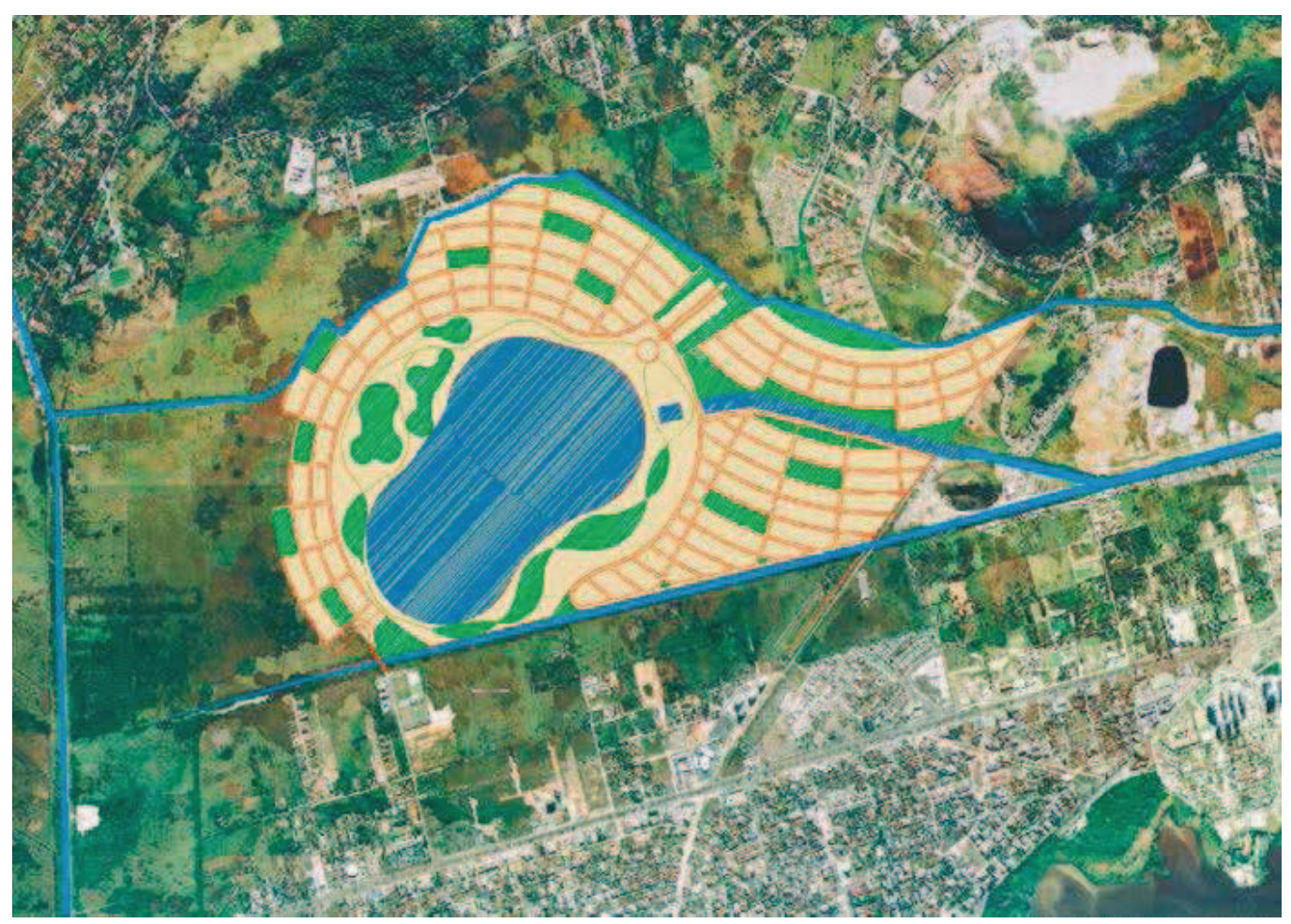

Figura 21 Proposta para loteamento conhecido como "Veneza Carioca".

Disponível em: <alfredosirkis.blogspot.com.br>. Acesso em: 15 de out. 2013. 
As ruas na região das Vargens têm larguras variadas, sendo que a menor dimensão é de 12 metros - mas a maioria delas possui largura superior a essa dimensão (figuras 22 a 26 ).

Consideramos que o tamanho desses logradouros, satisfatório para o sistema de espaços livres e a relação entre espaços públicos e privados, com calçadas com no mínimo 3 metros de largura, seria suficiente para a circulação de pedestres e a vitalidade do espaço urbano.

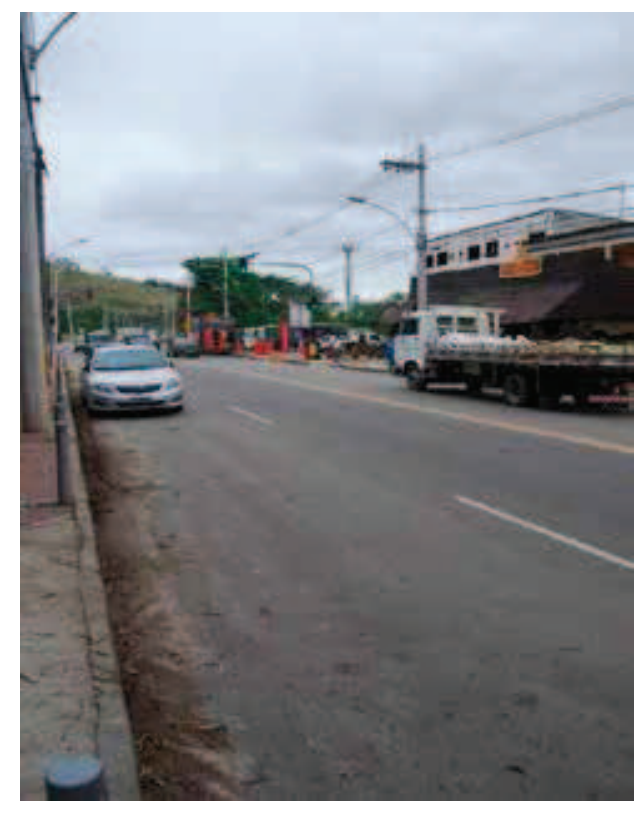

Figura 22

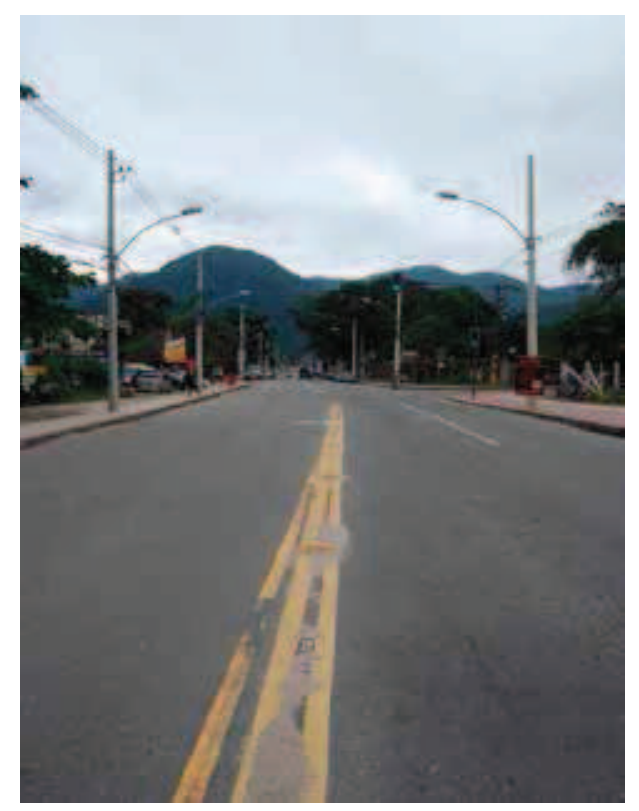

Figura 23

Figuras 22 e 23 Vista da Estrada dos Bandeirantes no setor C do PEU, trecho com maior vocação comercial da região. Atualmente apresenta pouca densidade e grande parte das suas construções não é regularizada. Fotos: Rogerio Goldfeld Cardeman - 2012. 


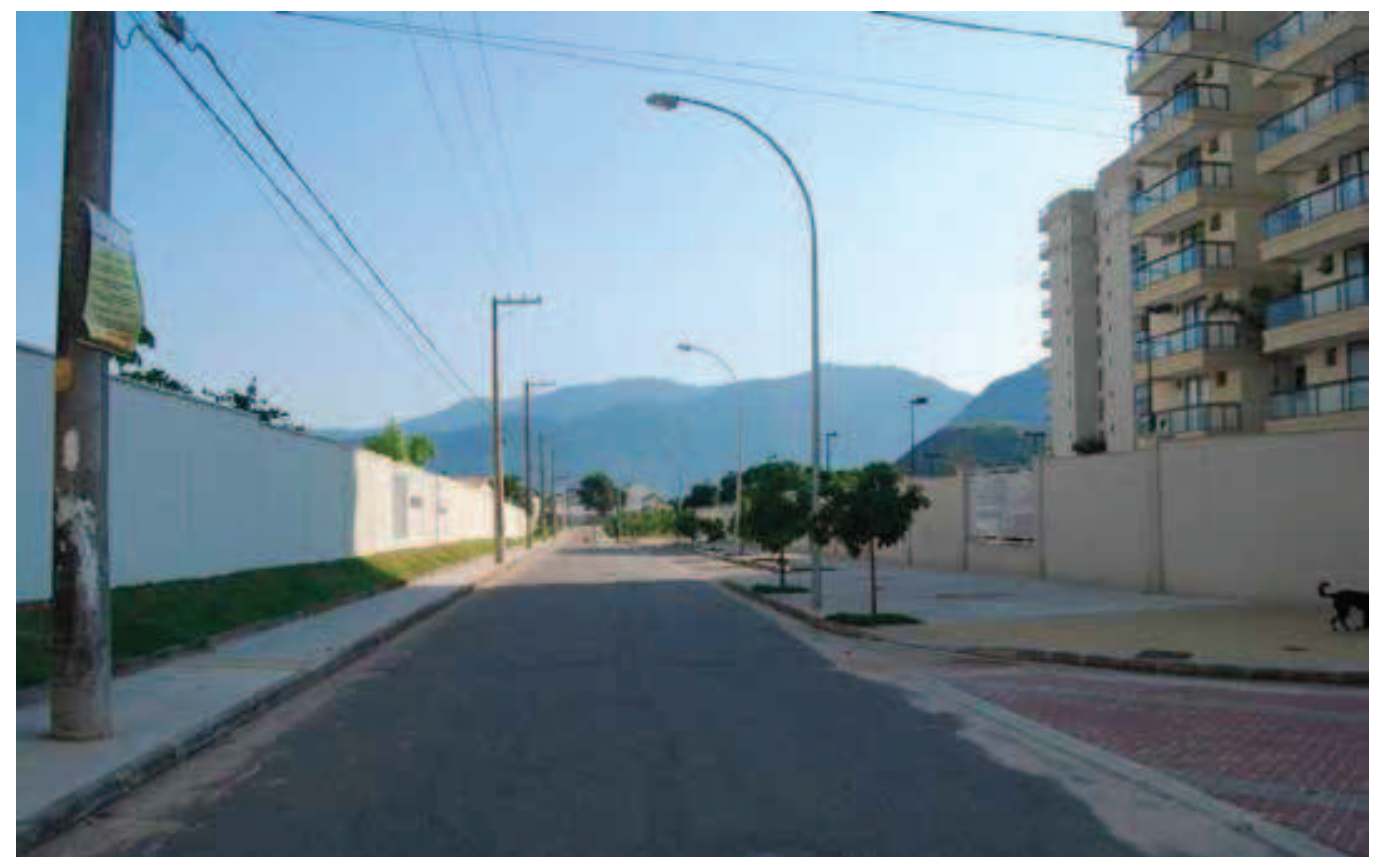

Figura 24 Vista das ruas no setor A, no Recreio dos Bandeirantes. Apesar das calçadas largas, não vemos pedestres utilizando o espaço da rua.

Foto: Rogerio Goldfeld Cardeman - 2013.

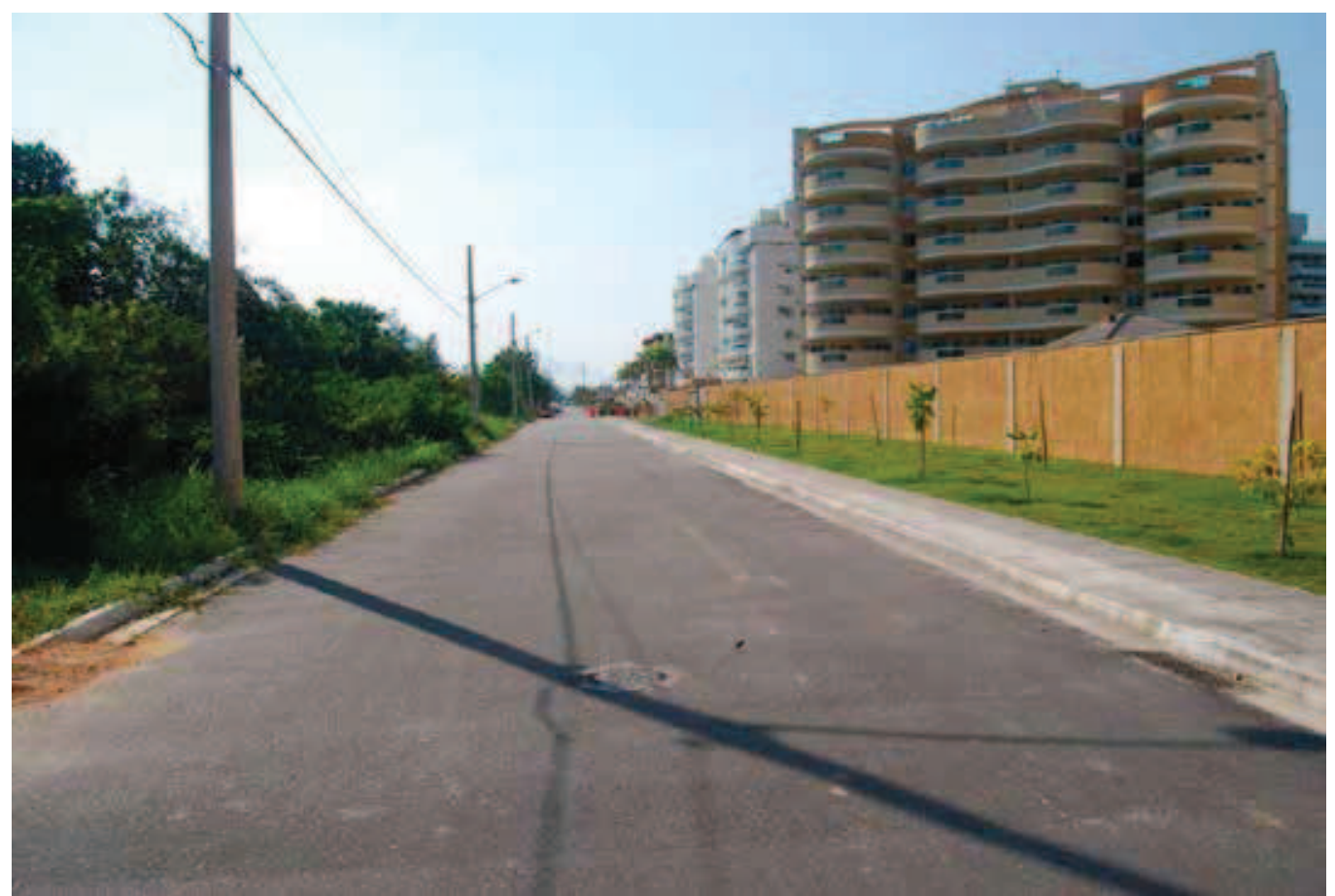

Figura 25 Os muros quebram a relação entre os espaços livres e edificados. Foto: Rogerio Goldfeld Cardeman - 2013. 


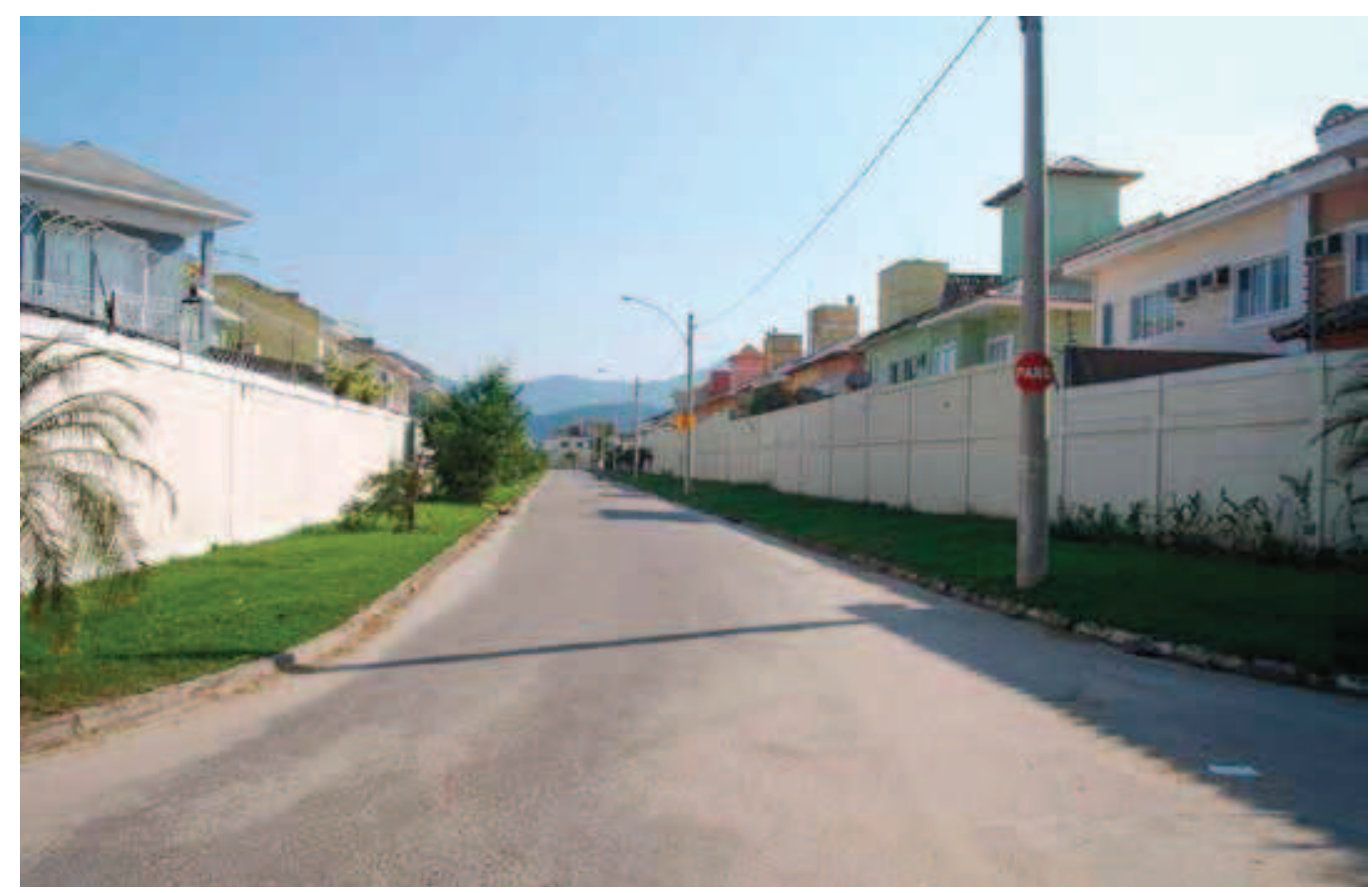

Figura $26 \bigcirc$ corredor de muros tira a possibilidade de apropriação da forma urbana da região. Foto: Rogerio Goldfeld Cardeman - 2013.

\section{CONSIDERAÇÕES FINAIS}

Os desafios da pesquisa, a partir de agora, incluem levantar dados da região que, diferentemente de áreas já consolidadas, possui baixo acervo de informações estatísticas. Plantas cadastrais produzidas em 2004 diferem de forma visível da situação encontrada no local, em que verificamos diversas ocupações, normalmente irregulares, que não aparecem nos cadastros nem tampouco nos mapas oficiais.

As discussões apresentadas neste artigo deverão orientar o rumo da pesquisa e promover o aparecimento de outras questões. Os trabalhos que os grupos de pesquisa SEL e Mudanças Climáticas estão desenvolvendo na região darão um arcabouço de dados importantes para determinar os impactos da provável ocupação desse espaço atualmente urbanizado, mas com características ainda agropastoris por parte do setor imobiliário.

As simulações dos cenários de ocupação a serem feitas deverão trazer luz à discussão sobre o processo de Planejamento Urbano e a criação dos PEU's na cidade do Rio de Janeiro, questionando, assim, o modelo atual de desenvolvimento de propostas urbanas, que não considera discussões abrangentes com os setores da sociedade. Essa tarefa fica restrita a alguns poucos técnicos municipais, que fazem pouco uso de pesquisas socioeconômicas e demográficas para estabelecer o perfil esperado para a ocupação de novas áreas da cidade. Além disso, as simulações podem determinar, ou ao menos auxiliar, a compreensão de como se conformarão os espaços livres e sua relação com a forma urbana da região das Vargens. 
Podemos também compreender os processos de valorização da terra urbana induzidos pelos atos do governo, como a introdução de novos parâmetros urbanísticos e investimentos infraestruturais em áreas frágeis que sofrerão grande transformação em sua paisagem, promovidas por essas ações.

Passamos, portanto, a questionar se todo espaço dentro dos limites legais das cidades devem ser objetos de planos urbanos, visando à sua ocupação, antes mesmo da completa saturação de áreas que já gozam de infraestrutura e que ainda não chegaram à sua capacidade máxima de absorver a população da cidade.

\section{REFERÊNCIAS BIBLIOGRÁFICAS}

COSTA, Lucio. Plano Piloto para urbanização da baixada compreendida entre a Barra da Tijuca, o Pontal de Sernambetiba e Jacarepaguá. Agência Jornalística Image, Rio de Janeiro, 1969.

FRIDMAN, Fania. Donos do Rio em nome do Rei: uma história fundiária da cidade do Rio de Janeiro. Rio de Janeiro: Jorge Zahar; Garamond, 1999, p. 125-232.

MONTEZUMA, Rita; OLIVEIRA Rogério. Os ecossistemas da Baixada de Jacarepaguá e o PEU das Vargens.

2010. Disponível em: <www.vitruvius.com.br>. Acesso em: 10 out. 2013.

NAME, Leonardo dos Passos Miranda. Análise da ocupação proposta pelo PEU das Vargens tendo como foco densidades, infraestruturas e condições ambientais. 2010. Disponível em: <www.vitruvius.com.br>. Acesso em: 10 out. 2013.

REDONDO, Andréa Albuquerque Garcia. PEU Vargens, ainda há tempo? 2009.

Disponível em: <www.vitruvius.com.br>. Acesso em: 10 out. 2013.

REZENDE, Vera. Planejamento urbano e ideologia: quatro planos para a cidade do Rio de Janeiro. Rio de Janeiro: Civilização Brasileira, 1982, p. 19-70.

RIO DE JANEIRO (CIDADE). Lei Complementar n 104, de 27 de novembro de 2009. Institui o Projeto de Estruturação Urbana - PEU Vargens, constituído pelos bairros de Vargem Grande, Vargem Pequena, Camorim e parte dos bairros do Recreio dos Bandeirantes, Barra da Tijuca e Jacarepaguá, nas XXIV e XVI Regiões Administrativas. Disponível em: <http://www.rio.ri.gov.br/web/smu>. Acesso em: 5 out. 2013.

VILLAÇA, Flávio. Uma contribuição para a história do planejamento urbano no Brasil. In: DEÁK, Csaba; SCHIFFER, Sueli Ramos (Org.). O processo de urbanização no Brasil. São Paulo: Edusp, 1999, p. 169-243.

\section{ENTREVISTA}

Armando Abreu concedeu entrevista a Rogerio Goldfeld Cardeman em 6 jul. 2012 - Rio de Janeiro. 
Rogerio Goldfeld Cardeman 